\title{
Limonoids from Andiroba Oil and Cedrela fissilis and their Insecticidal Activity
}

\author{
Alessandra R. P. Ambrozin, ${ }^{a}$ Ana C. Leite, ${ }^{a}$ Fabiana C. Bueno, ${ }^{b}$ Paulo C. Vieira, ${ }^{*, a}$ \\ João B. Fernandes, ${ }^{a}$ Odair C. Bueno, ${ }^{b}$ M. Fátima das G. Fernandes da Silva, ${ }^{a}$ \\ Fernando C. Pagnocca, ${ }^{b}$ M. José A. Hebling ${ }^{b}$ and Maurício Bacci Jr. ${ }^{b}$ \\ ${ }^{a}$ Departamento de Química, Universidade Federal de São Carlos, CP 676, 13565-905 São Carlos - SP, Brazil \\ ${ }^{b}$ Centro de Estudos de Insetos Sociais, Universidade Estadual Paulista, CP 199, 13506-900 Rio Claro - SP, Brazil
}

\begin{abstract}
Nove limonóides foram isolados de Carapa guianensis e Cedrela fissilis. Entre eles, a 1,2-diidro-3ß-hidroxi-7-desacetoxi-7-oxogedunina é uma substância inédita. Além disso, alguns deslocamentos químicos da xilocensina $\mathrm{k}$ foram corrigidos e os dados de RMN ${ }^{1} \mathrm{H}$ da 7-desacetilgedunina são descritos pela primeira vez na literatura. Seis dos limonóides isolados foram submetidos a ensaios com formigas Atta sexdens rubropilosa e apresentaram atividade inseticida moderada.
\end{abstract}

\begin{abstract}
Nine limonoids were isolated from Carapa guianensis and Cedrela fissilis. Among them, 1,2-dihydro-3 $\beta$-hydroxy-7-deacetoxy-7-oxogedunin is a new compound. Moreover, the assignments of some chemical shifts of xyloccensin $k$ have been corrected and ${ }^{1} \mathrm{H}$ NMR data of 7-deacetylgedunin have been assigned for the first time. These isolated limonoids were assayed on Atta sexdens rubropilosa workers showing moderate insecticidal activities.
\end{abstract}

Keywords: Meliaceae, Carapa guianensis, Cedrela fissilis, limonoids, insecticidal activity

\section{Introduction}

The family Meliaceae includes many plants that are sources of valuable timber and many that have wideranging uses in ethnomedicine. The family is distinguished by the occurrence of characteristic substances called limonoids. ${ }^{1}$ These substances have wide spectrum of biological activities, ${ }^{2}$ particularly insecticidal action. ${ }^{3}$

The leaf-cutting ants of the genera Atta and Acromyrmex use mostly fresh plant fragments to raise their symbiotic fungi ${ }^{4,5}$ and are the cause of considerable economic damage, due to defoliation that they cause. ${ }^{6}$ Control of this pest is still problematic, presenting only temporary effects and is sometimes, harmful to the environment, to man and other animals. ${ }^{6,7}$ Consequently, an extensive search for alternate methods to control these insects has been made in an attempt to substitute traditional agrochemicals with agents that yield faster decay, higher specificity and, therefore, less damaging to the environment. In this context, plants are considered a promising source for less toxic compounds that could be used as a soft control method.

* e-mail: paulo@dq.ufscar.br
As a part of our search for new natural insecticides against leaf-cutting ants ${ }^{8}$ and because of the fact that limonoids have displayed biological activity towards a variety of insects, we decided to investigate the effect of limonoids isolated from two species of Meliaceae family, Carapa guianensis Aubl. and Cedrela fissilis Vell. on Atta sexdens rubropilosa.

Carapa guianensis is a tall tree that grows wild throughout South America, West India and South Africa. In Brazil, it can be found prevalently in areas of the Amazon rainforest, that are rich in soils and swamps. From the nuts of this plant is extracted an oil, called andiroba oil, which has a long history of traditional use in South America, such as analgesic, anti-inflammatory, insecticide, antibacterial, anti-parasitic and as an anti-cancer remedy. ${ }^{9-12}$

Andiroba oil is rich in fatty acids such as oleic, palmitic, stearic and linoleic acids, together with $2-5 \%$ of unsaponificable material. In addition, from several parts of Carapa guianensis have been isolated limonoids, triterpenes, steroids, coumarins, flavonoids and diglycerides. ${ }^{13-18}$

C. fissilis tree, known as "cedro" (cedar), is a valuable source of timber. In Brazil, it can be found from the Amazon forest as far south as Espírito Santo State. Previous investigation of fruits and seeds from this species 
afforded the limonoids fissinolide, mexicanolide and $3 \beta$-hydroxyisomexicanolide. ${ }^{19}$

Extracts and fractions from C. fissilis and one commercial $C$. guianensis oil showed to have activity against $A$. sexdens rubropilosa workers. ${ }^{20,21}$ In the herein study we report the insecticidal activities towards $A$. sexdens rubropilosa of six gedunin derivatives limonoids obtained from these active fractions besides spectroscopic data for 1,2-dihydro-3 $\beta$-hydroxy-7-deacetoxy-7-oxogedunin (5), 7-deacetylgedunin (6) and xyloccensin $\mathrm{k}(\mathbf{9})$.

\section{Results and Discussion}

The chemical investigation of one commercial andiroba oil sample afforded seven limonoids: 17ß-hydroxyazadiradione (1), gedunin (2), 6 $\alpha$-acetoxygedunin (3), 7-deacetoxy-7-oxogedunin (4), 1,2-dihydro$3 \beta$-hydroxy-7-deacetoxy-7-oxogedunin (5), methyl angolensate (8) and xyloccensin k (9). Moreover, from roots and leaves of $C$. fissilis were isolated 7-deacetylgedunin (6) and photogedunin (7) along with limonoids

\section{2, 3, 4 and 5 .}

Compounds 1, 2 and 9 have been isolated for the first time from $C$. guianensis and all the limonoids isolated from $C$. fissilis are new for this species. Compound $\mathbf{5}$ is new to the literature.

Limonoids $\mathbf{1},{ }^{22} 2,{ }^{23} 3,{ }^{13} 4,{ }^{15} \mathbf{7},{ }^{24}$ and $\mathbf{8}^{25}$ were identified by comparison of their NMR spectral data to those previously reported in the literature. The ${ }^{1} \mathrm{H}$ NMR data of compound 6 (Table 1) supplement and expand some hydrogen and carbon chemical shifts reported by Ekong and Olagbemi. ${ }^{26}$

Compound 5 was isolated as a white powder from C. fissilis leaves and from andiroba oil and identified by spectroscopic methods. It is a new compound, whose 3-OH epimer was obtained from Guarea thompsonii. ${ }^{27}$

The ${ }^{1} \mathrm{H}$ and ${ }^{13} \mathrm{C}$ NMR spectra of $\mathbf{5}$ exhibited signals at: $\delta_{\mathrm{H}} 7.40(\mathrm{~m}), 7.36(\mathrm{~m}), 6.36(\mathrm{~s})$ and $\delta_{\mathrm{C}} 143.0,141.0,120.4$, 109.9 of a $\beta$-furanyl ring; $\delta_{\mathrm{H}} 1.13(\mathrm{~s}), 1.12(\mathrm{~s}), 1.08(\mathrm{~s})$, $0.98(\mathrm{~s}), 0.84(\mathrm{~s})$ and $\delta_{\mathrm{C}} 27.4,20.9,17.1,16.9,14.8$ related to five tert-methyl groups; $\delta_{\mathrm{H}} 5.45(\mathrm{~s}), 3.83(\mathrm{~s})$ and $\delta_{\mathrm{C}}$ 167.3, 65.7, 53.6, 78.1 corresponding to a lactone D-ring with an epoxide between C-14 and C-15. These features are characteristics of compounds classified in the gedunin group of limonoids. However, the NMR spectra of compound 5 lacked signals related to the A-ring $\alpha, \beta$-insaturated ketone. In contrast, signals were observed at $\delta_{\mathrm{H}} 3.26(\mathrm{dd}, 11.0$ and $5.0 \mathrm{~Hz})$ and $\delta_{\mathrm{C}} 78.2$. These signals indicated an equatorial hydroxyl group at C-3. Thus, limonoid 5 was identified as 1,2-dihydro-3 $\beta$-hydroxy-7deacetoxy-7-oxogedunin and its spectral data allocations
Table 1. NMR spectral data of limonoids 5 and 6

\begin{tabular}{|c|c|c|c|}
\hline $\mathrm{H} / \mathrm{C}$ & $\delta_{\mathrm{H}}$ of $\mathbf{5}^{\mathrm{a}}$ & $\delta_{C}$ of $5^{b}$ & $\delta_{\mathrm{H}}$ of $\mathbf{6}^{\mathrm{b}}$ \\
\hline 1 & & 38.3 & $7.11 \mathrm{~d}(J 10.2 \mathrm{~Hz})$ \\
\hline 2 & $1.75 \mathrm{~m}$ & 26.9 & $5.85 \mathrm{~d}(J 10.2 \mathrm{~Hz})$ \\
\hline 3 & $3.26 \mathrm{dd}(J 11.0 ; 5.0 \mathrm{~Hz})$ & 78.2 & \\
\hline 4 & & 39.5 & \\
\hline 5 & $1.29 \mathrm{dd}(J 14.1 ; 3.1 \mathrm{~Hz})$ & 56.8 & $2.49 \mathrm{dd}(J 13.4 ; 2.4 \mathrm{~Hz})$ \\
\hline 6 & $\begin{array}{l}6 \alpha: 2.40 \mathrm{dd}(J 13.9 ; 3.1 \mathrm{~Hz}) \\
6 \beta: 2.75 \mathrm{dd}(J 14.1 ; 13.9 \mathrm{~Hz})\end{array}$ & 36.5 & $1.92 \mathrm{~m}, 1.83 \mathrm{~m}$ \\
\hline 7 & & 210.0 & 3.58 br s \\
\hline 8 & & 52.9 & \\
\hline 9 & $1.90 \mathrm{~m}$ & 52.4 & $2.58 \mathrm{~m}$ \\
\hline 10 & & 37.5 or 37.6 & \\
\hline 11 & $1.60 \mathrm{~m}$ & 16.8 & $2.00 \mathrm{~m}, 1.81 \mathrm{~m}$ \\
\hline 12 & & 32.4 & $1.70 \mathrm{~m}, 1.57 \mathrm{~m}$ \\
\hline 13 & & 37.5 or 37.6 & \\
\hline 14 & & 65.7 & \\
\hline 15 & $3.83 \mathrm{~s}$ & 53.6 & $3.91 \mathrm{~s}$ \\
\hline 16 & & 167.3 & \\
\hline 17 & $5.45 \mathrm{~s}$ & 78.1 & $5.60 \mathrm{~s}$ \\
\hline 18 & $1.12 \mathrm{~s}$ & 20.9 & $1.24 \mathrm{~s}$ \\
\hline 19 & $1.08 \mathrm{~s}$ & 16.9 & $1.20 \mathrm{~s}$ \\
\hline 20 & & 120.4 & \\
\hline 21 & $7.40 \mathrm{~m}$ & 141.0 & $7.41 \mathrm{~m}$ \\
\hline 22 & $6.36 \mathrm{~s}$ & 109.9 & $6.35 \mathrm{~m}$ \\
\hline 23 & $7.36 \mathrm{~m}$ & 143.0 & $7.41 \mathrm{~m}$ \\
\hline 28 & 0.84 or $0.98 \mathrm{~s}$ & 14.8 or 27.4 & $1.09 \mathrm{~s}$ \\
\hline 29 & 0.84 or $0.98 \mathrm{~s}$ & 14.8 or 27.4 & $1.10 \mathrm{~s}$ \\
\hline 30 & $1.13 \mathrm{~s}$ & 17.1 & $1.15 \mathrm{~s}$ \\
\hline
\end{tabular}

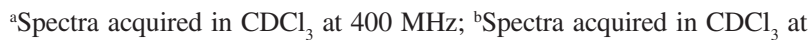
$100 \mathrm{MHz}$; coupling constant $J$ in parenthesis.

(Table 1) were established unequivocally through 1D and 2D NMR experiments.

Compound 9 was isolated as a white powder from andiroba oil. It is classified as belonging to the mexicanolide group of limonoids and contains a tetrahydrofuran sub-unit with an oxygen bridge linking from $\mathrm{C}-3$ to $\mathrm{C}-8$. It was also isolated from the seed of Xylocarpus granatum. ${ }^{28}$ However, we found through 2D NMR spectra analysis that some chemical shifts were incorrectly determined by Kokpol et al. ${ }^{28}$ among them H-17, H-28, H-29, C-8, C-17, C-18 and C-29.

The chemical shift of $\mathrm{C}-17$ was deduced from ${ }^{1} \mathrm{~J}$ correlation between $\mathrm{H}-17(\delta 6.28, \mathrm{~s})$ and one carbon at $\delta$ 76.5. H-18 $(\delta 1.00, \mathrm{~s})$ was assigned through ${ }^{3} J$ correlation between the methyl hydrogens and carbinolic carbon at $\delta$ $76.5(\mathrm{C}-17)$. Furthermore, $\mathrm{H}-28(\delta 1.12)$ and $\mathrm{H}-29(\delta 0.67)$ were determined through ${ }^{3} J$ correlation to C-3 $(\delta$ 91.4). Finally, the ${ }^{2} J-{ }^{3} J$ correlations among H-30 $(\delta$ 2.52, dd, 12.4 and $6.1 \mathrm{~Hz}), \mathrm{H}-2(\delta 2.98$, br t, $6.1 \mathrm{~Hz})$ and a quaternary carbon at $\delta 85.2$ established C-8.

Some of the limonoids isolated from C. guianensis and $C$. fissilis were evaluated for their effects on A. sexdens rupropilosa ants. The results (Table 3) showed that control and limonoid-treated groups had on average the same 
Table 2. NMR spectral data of limonoid 9

\begin{tabular}{|c|c|c|c|c|}
\hline \multirow[b]{2}{*}{ Carbon } & \multicolumn{2}{|r|}{ HSQC } & \multicolumn{2}{|c|}{$\mathrm{HMBC}$} \\
\hline & $\delta_{\mathrm{C}}$ & $\delta_{\mathrm{H}}\left({ }^{1} J_{\mathrm{C}-\mathrm{H}}\right)$ & ${ }^{2} J_{\mathrm{C}-\mathrm{H}}$ & ${ }^{3} J_{\mathrm{C}-\mathrm{H}}$ \\
\hline 1 & 214.9 & & & \\
\hline 2 & 49.0 & $2.98 \mathrm{brt}(J 6.1 \mathrm{~Hz})$ & 214.9 & 85.2 \\
\hline 3 & 91.4 & $4.23 \mathrm{~d}(J 6.1 \mathrm{~Hz})$ & & $43.0,214.9$ \\
\hline 4 & 37.2 & & & \\
\hline 5 & 43.0 & $3.08 \mathrm{dd}(J 10.7 ; 2.4 \mathrm{~Hz})$ & & \\
\hline 6 & 32.6 & $2.23 \mathrm{~d}(J 10.7 \mathrm{~Hz})$ & & 37.2 \\
\hline 7 & 174.4 & & & \\
\hline 8 & 85.2 & & & \\
\hline 9 & 52.2 & $1.97 \mathrm{dd}(J 12.4 ; 4.7 \mathrm{~Hz})$ & & \\
\hline 10 & 51.1 & & & \\
\hline 11 & 17.9 & $1.46 \mathrm{~m}, 2.10 \mathrm{~m}$ & & \\
\hline 12 & 28.8 & $1.50 \mathrm{~m}, 1.70 \mathrm{~m}$ & & \\
\hline 13 & 40.0 & & & \\
\hline 14 & 74.7 & & & \\
\hline 15 & 37.3 & $2.52 \mathrm{~d}(J 17.8 \mathrm{~Hz}), 3.16 \mathrm{~d}(J 17.8 \mathrm{~Hz})$ & $74.7,169.9$ & \\
\hline 16 & 169.9 & & & \\
\hline 17 & 76.5 & $6.28 \mathrm{~s}$ & 120.1 & 143.0 \\
\hline 18 & 16.2 & $1.00 \mathrm{~s}$ & 40.0 & $28.8,74.7,76.5$ \\
\hline 19 & 16.9 & $0.95 \mathrm{~s}$ & 51.1 & $43.0,52.2,214.9$ \\
\hline 20 & 120.1 & & & \\
\hline 21 & 143.0 & 7.45 br s & & \\
\hline 22 & 110.0 & $6.49 \mathrm{br} \mathrm{s}$ & & \\
\hline 23 & 140.9 & $7.56 \mathrm{br} \mathrm{s}$ & & \\
\hline 28 & 28.1 & $1.12 \mathrm{~s}$ & 37.2 & $20.2,43.0,91.4$ \\
\hline 29 & 20.2 & $0.67 \mathrm{~s}$ & 37.2 & $28.1,43.0,91.4$ \\
\hline 30 & 42.5 & $2.04 \mathrm{~d}(J 12.4 \mathrm{~Hz}), 2.52 \mathrm{dd}(J 12.4,6.1 \mathrm{~Hz})$ & $49.0,85.2$ & $52.2,214.9$ \\
\hline $\mathrm{COOCH}_{3}$ & 52.0 & $3.70 \mathrm{~s}$ & & 174.4 \\
\hline $\mathrm{COOCH}_{3}^{3}$ & 174.4 & & & \\
\hline
\end{tabular}

Spectra acquired in $\mathrm{CDCl}_{3}, 9.8 \mathrm{~T}$; coupling constant $J$ in parenthesis.

survival medium time. Compound $\mathbf{3}$ showed significant difference to the control according to the log-rank test $(p<0.05)$, which takes into account the whole test period. The gedunin type limonoids do not seem to be highly active against these ants. Indeed, $C$-seco limonoids, such as azadirachtin, are more active insecticidal compound, possessing both antifeedant and growth-regulating activities. ${ }^{2,29}$ The toxicity for the ants observed for the C. fissilis and C. guianensis extracts seems not to be related only to the presence of the limonoids. Perhaps the limonoids act in synergism between them or with other compounds in the extracts.

\section{Experimental}

\section{General experimental procedures}

The ${ }^{1} \mathrm{H}$ NMR, ${ }^{13} \mathrm{C}$ NMR and $2 \mathrm{D}$ correlation spectra were obtained in $\mathrm{CDCl}_{3}$ using Bruker DRX-200 and ARX400 NMR spectrometers, and using tetramethylsilane (TMS) as internal standard. HPLC was carried out using a preparative LC-8A Shimadzu system with SPD-6AV Shimadzu UV detector.

\section{Plant material}

The roots and leaves of Cedrela fissilis Vell. were collected in São Carlos-SP, Brazil in June 01, 2001 and identified by Dr. Maria Inês Salgueiro Lima from the Department of Botany, Universidade Federal de São Carlos, where a voucher specimen (6701) was deposited. The commercial andiroba oil sample was purchased in Belém city (Pará, Brazil), in 1996.

\section{Isolation of the limonoids from Carapa guianensis}

A portion of andiroba oil sample $(21.0 \mathrm{~g})$ was submitted to vacuum liquid chromatography (VLC) on silica gel (70-230 mesh) using a hexane- $\mathrm{CH}_{2} \mathrm{Cl}_{2}$-EtOAc$\mathrm{MeOH}$ gradient, to yield the four corresponding fractions $(\mathrm{H}, \mathrm{D}, \mathrm{Ac}, \mathrm{Me})$. The fraction Ac (2.6 g) was subjected to column chromatography over silica gel (230-400 mesh, $267 \times 38 \mathrm{~mm}$ i.d., stepwise with a hexane $\rightarrow \mathrm{MeOH}$ gradient) to give three fractions. The second fraction (Ac2; $2.3 \mathrm{~g}$ ) was chromatographed on a silica gel column (230-400 mesh, 264 x $45 \mathrm{~mm}$ i.d.) and eluted with solvents of increasing polarity 
Table 3. Activities of gedunin limonoids on Atta sexdens rubropilosa workers at $100 \mu \mathrm{g} \mathrm{mL}^{-1}$

\begin{tabular}{cc}
\hline Limonoid & Survival median $\left(\mathrm{S}_{50}\right) /$ days \\
\hline $\mathbf{2}$ & 8 \\
$\mathbf{3}$ & $8^{a}$ \\
$\mathbf{4}$ & 11 \\
$\mathbf{5}$ & 9 \\
$\mathbf{6}$ & 9 \\
$\mathbf{7}$ & 9 \\
control & 10 \\
\hline
\end{tabular}

${ }^{a}$ Significant difference according to the log-rank test $(\mathrm{p}<0.05)$.

(hexane $\rightarrow \mathrm{MeOH}$ ) yielding five fractions. Limonoid $\mathbf{5}$ (Ac2,4,2; $17.7 \mathrm{mg}$ ) was isolated from fraction four (Ac2,4; $458.2 \mathrm{mg}$ ) using column chromatography over silica gel (230-400 mesh, 444 x $24 \mathrm{~mm}$ i.d., stepwise with a hexane: $\mathrm{CH}_{2} \mathrm{Cl}_{2}$ :acetone $\rightarrow \mathrm{MeOH}$ gradient). The fifth fraction $($ Ac2, 4,$5 ; 409.0 \mathrm{mg})$ of this last step was subjected to column chromatography over silica gel (230-400 mesh, 475 × $24 \mathrm{~mm}$ i.d., stepwise with a hexane: $\mathrm{CH}_{2} \mathrm{Cl}_{2}$ :acetone $\rightarrow \mathrm{MeOH}$ gradient) to give seven fractions. Fraction three (Ac2,4,5,3; $19.8 \mathrm{mg}$ ) was subjected to preparative HPLC (Hypersil $5 \mu$ column, 290 x $10 \mathrm{~mm}$ i.d., eluted with hexane:isopropanol (9:1), flow rate: $3 \mathrm{~mL} \mathrm{~min}^{-1}$, detector $\mathrm{UV}$ at $240 \mathrm{~nm}$ ) and the limonoid 9 (Ac2,4,5,3,4; $2.7 \mathrm{mg}$ ) was isolated.

Another portion of the andiroba oil sample $(150.0 \mathrm{~g})$ was submitted to VLC on silica gel (70-230 mesh) using a hexane$\mathrm{CH}_{2} \mathrm{Cl}_{2}$-EtOAc-MeOH gradient, to yield four fractions $(\mathrm{FH}$, FD, FA, FM). Fraction FA (19.0 g) was subjected to column chromatography over silica gel (230-400 mesh, 309 x 38 $\mathrm{mm}$ i.d., stepwise with a hexane: $\mathrm{CH}_{2} \mathrm{Cl}_{2}$ :acetone $\rightarrow \mathrm{MeOH}$ gradient) to give nine fractions. Several chromatographies of fractions five, seven and eight (FA5, FA7 and FA8) afforded limonoids $1,2,3,4,8$, as described below.

The fifth fraction (FA5; $1.1 \mathrm{~g}$ ) was chromatographed on a silica gel column (230-400 mesh, 269 × $32 \mathrm{~mm}$ i.d.) and eluted with solvents of increasing polarity (hexane: $\mathrm{CH}_{2} \mathrm{Cl}_{2}$ :acetone $\rightarrow \mathrm{MeOH}$ ) to afford nine fractions. The limonoids 2 (FA5,6,4; $4.5 \mathrm{mg}$ ) and 3 (FA5,6,3;1.5 mg) were isolated from fraction six (FA5,6; $30.1 \mathrm{mg}$ ) by preparative HPLC (Asahipak GS-310 2G polymeric column, 500 x $22 \mathrm{~mm}$ i.d., eluted with $\mathrm{MeOH}$ (100\%), flow rate: $5 \mathrm{~mL} \mathrm{~min}^{-1}$, detector $\mathrm{UV}$ at $220 \mathrm{~nm}$ ).

Fraction seven (FA7; $338.4 \mathrm{mg}$ ) was chromatographed on a silica gel column (230-400 mesh, 466 x $24 \mathrm{~mm}$ i.d.) and eluted with solvents of increasing polarity (hexane: $\mathrm{CH}_{2} \mathrm{Cl}_{2}$ :acetone $\rightarrow \mathrm{MeOH}$ ) to afford seven fractions. The fourth fraction (FA7,4; $164.0 \mathrm{mg}$ ) was subjected to column chromatography over silica gel (230-400 mesh, 420 $\mathrm{x} 24 \mathrm{~mm}$ i.d.) and eluted with solvents of increasing polarity (hexane: $\mathrm{CH}_{2} \mathrm{Cl}_{2}$ :acetone $\rightarrow \mathrm{MeOH}$ ) to yield five fractions.
Through preparative HPLC (Asahipak GS-310 2G polymeric column, 500 x $22 \mathrm{~mm}$ i.d., eluted with $\mathrm{MeOH}$

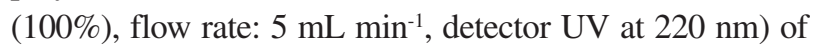
fraction two (FA7,4,2; $38.9 \mathrm{mg}$ ) were isolated the limonoids 4 (FA7,4,2,3; $5.8 \mathrm{mg}$ ) and 8 (FA7,4,2,4; $17.4 \mathrm{mg}$ ).

Fraction eight (FA8; $342.9 \mathrm{mg}$ ) was chromatographed on a silica gel column (230-400 mesh, 342 x $24 \mathrm{~mm}$ i.d.) and eluted with solvents of increasing polarity (hexane: $\mathrm{CH}_{2} \mathrm{Cl}_{2}$ :acetone $\rightarrow \mathrm{MeOH}$ ) to afford six fractions. The fourth fraction (FA8,4; $195.4 \mathrm{mg}$ ) was subjected to column chromatography over silica gel (230-400 mesh, 473 x 24 $\mathrm{mm}$ i.d.) and eluted with solvents of increasing polarity $\left(\mathrm{CH}_{2} \mathrm{Cl}_{2}\right.$ :acetone $\left.\rightarrow \mathrm{MeOH}\right)$ to yield nine fractions. Limonoid 1 (FA8, 4,6, 2; $6.6 \mathrm{mg}$ ) was isolated from fraction six (FA8,4,6; $15.3 \mathrm{mg}$ ) through preparative HPLC (Hypersil 5m column, 290 x $10 \mathrm{~mm}$ i.d., eluted with hexane:isopropanol (9:1), flow rate: $3 \mathrm{~mL} \mathrm{~min}^{-1}$, detector $\mathrm{UV}$ at $240 \mathrm{~nm}$ ).

\section{Isolation of the limonoids from Cedrela fissilis}

The powdered air-dried roots from $C$. fissilis were extracted by maceration for three times $(72 \mathrm{~h}$ ) with hexane, dichloromethane and and/or methanol at room temperature. The solvent was removed under reduced pressure by rotary evaporation. A portion of the hexane extract $(3.5 \mathrm{~g})$ from roots of $C$. fissilis $(\mathrm{RH})$ was submitted to VLC on silica gel (70-230 mesh) using a hexane$\mathrm{CH}_{2} \mathrm{Cl}_{2}$-EtOAc-MeOH gradient. The ethyl acetate-soluble fraction (704 mg) was chromatographed on silica gel (230400 mesh), and eluted with hexane- $\mathrm{CH}_{2} \mathrm{Cl}_{2}$-acetone (6:3:1) to give 5 fractions $(\mathbf{A} \rightarrow \mathbf{E})$. Fraction $\mathbf{E}$ was twice chromatographed as above to give four fractions. Fraction E-4 was submitted to HPLC [Asahipak GS-310 2G polymeric column, 500 x $22 \mathrm{~mm}$ i.d., eluted with $\mathrm{MeOH}$ (100\%), at a flow rate of $5 \mathrm{~mL} \mathrm{~min}{ }^{-1}$, detector $\mathrm{UV}$ at $254 \mathrm{~nm}$ ] affording $\mathbf{2}(13.1 \mathrm{mg})$ and $\mathbf{3}(2.5 \mathrm{mg})$.

The powdered air-dried leaves from $C$. fissilis were extracted by maceration as described above. The $\mathrm{CH}_{2} \mathrm{Cl}_{2}$ extract $(29.0 \mathrm{~g})$ from leaves of $C$. fissilis (LH) was submitted to VLC as described to the hexane extract from roots $(\mathrm{RH})$. The $\mathrm{CH}_{2} \mathrm{Cl}_{2}$-soluble fraction $(6.0 \mathrm{~g})$ was chromatographed on silica gel (70-230 mesh)-florisil (1:1), with a hexane- $\mathrm{CH}_{2} \mathrm{Cl}_{2}-\mathrm{MeOH}$ gradient to afford 9 fractions $(\mathrm{A} \rightarrow \mathrm{I})$. Fraction $\mathbf{D}$ was three times chromatographed with hexane- $\mathrm{CH}_{2} \mathrm{Cl}_{2}-\mathrm{MeOH}$ (6:3.5:0.5) to give $4(8.3 \mathrm{mg})$ and $\mathbf{6}(5.1 \mathrm{mg})$. Fraction I was also chromatographed three times over silica gel (230-400 mesh), eluted with hexane- $\mathrm{CH}_{2} \mathrm{Cl}_{2}$-acetone $(7: 2: 1)$ yielding 9 fractions. Fraction I-3 was purified by HPLC [Hypersil $5 \mu$ column, $290 \times 10 \mathrm{~mm}$ i.d., eluted with hexane:isopropanol $(8: 2)$, flow rate: $2.5 \mathrm{~mL} \mathrm{~min}^{-1}$, 


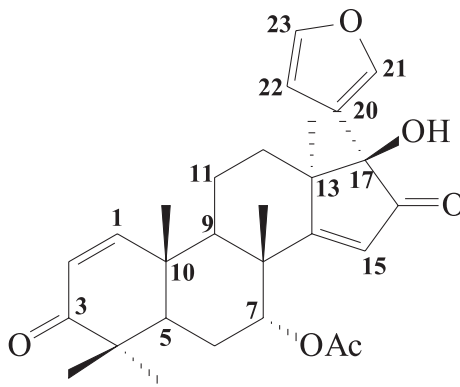

1

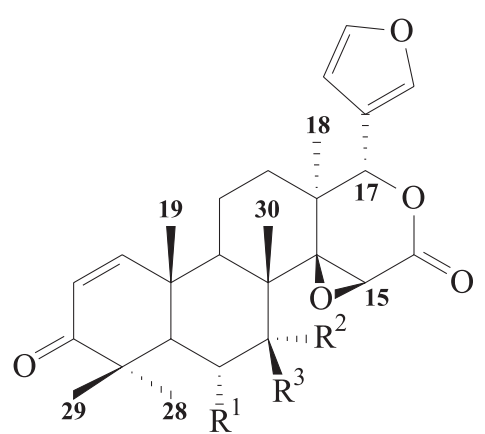

2: $\mathrm{R}^{1}=\mathrm{R}^{3}=\mathrm{H} ; \mathrm{R}^{2}=\mathrm{OAc}$

3: $\mathrm{R}^{1}=\mathrm{R}^{2}=$ OAc, $\mathrm{R}^{3}=\mathrm{H}$

4: $\mathrm{R}^{1}=\mathrm{H} ; \mathrm{R}^{2}=\mathrm{R}^{3}=\mathrm{O}$

6: $\mathrm{R}^{1}=\mathrm{R}^{3}=\mathrm{H}, \mathrm{R}^{2}=\mathrm{OH}$

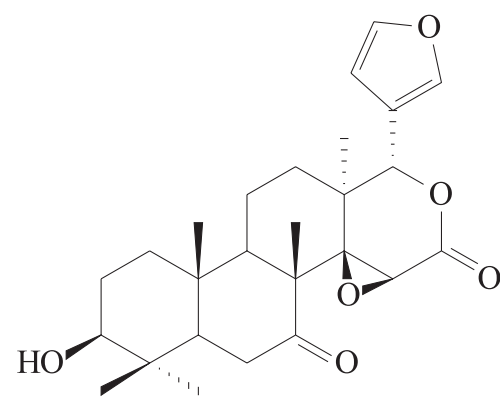

5<smiles>CC(=O)O[C@H]1C[C@H]2C(C)(C)C(=O)C=C[C@]2(C)[C@H]2CC[C@H](C3=C[C@H](O)OC3=O)[C@@]3(C)O[C@H]3C(=O)O[C@H]12</smiles>

7

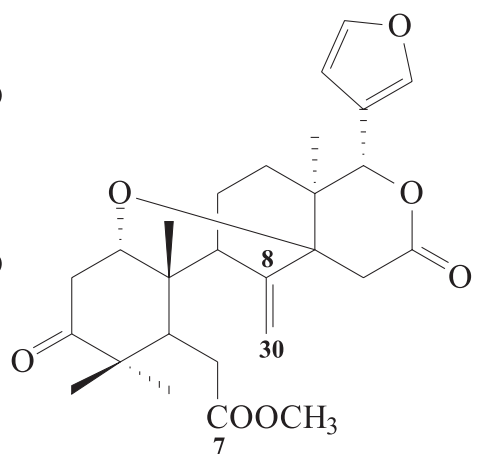

8

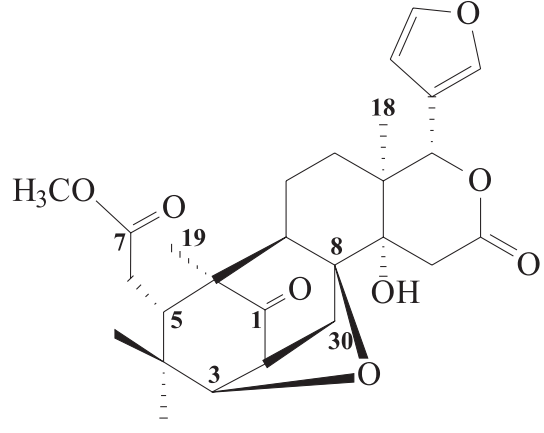

9

Figure 1. Limonoids isolated from Carapa guianensis and Cedrela fissilis.

detector UV at $240 \mathrm{~nm}$ ] to give $\mathbf{5}(1.2 \mathrm{mg})$. Fraction $\mathbf{I}-\mathbf{8}$ was chromatographed on Sephadex LH-20, with $\mathrm{MeOH}$ $(100 \%)$ to afford $7(10.3 \mathrm{mg})$.

\section{1,2-dihydro-3ß-hydroxy-7-deacetoxy-7-oxogedunin (5)}

White powder; $[\alpha]_{\mathrm{D}}=-72.8^{\circ}\left(c 0.32, \mathrm{CH}_{2} \mathrm{Cl}_{2}\right)$; UV $\left(\mathrm{CH}_{2} \mathrm{Cl}_{2}\right) \lambda_{\max } / \mathrm{nm}$ : 236; IR (film) $v_{\text {max }} / \mathrm{cm}^{-1}: 3054,2986$, 1741, 1709, 1265, 1029; ${ }^{1} \mathrm{H}$ NMR $\left(\mathrm{CDCl}_{3}, 400 \mathrm{MHz}\right)$ : Table $1 ;{ }^{13} \mathrm{C}$ NMR $\left(\mathrm{CDCl}_{3}, 100 \mathrm{MHz}\right)$ : Table 1.

\section{Bioassays}

The A. sexdens rubropilosa workers used in the assays were randomly removed from laboratory nests. They had a combined body mass of 20-25 mg. Before assaying the nests were supplied daily with leaves of Eucalyptus sp., oat seeds and occasionally with leaves of other plants such as Hibiscus sp., Ligustrum sp. or rose petals. Fifty ants were randomly removed from the nests and distributed to five Petri dishes (ten ants each) for each treatment. During the assays the ants were maintained on an artificial diet consisting of glucose (50 $\left.\mathrm{g} \mathrm{L}^{-1}\right)$, bacto-peptone $\left(10 \mathrm{~g} \mathrm{~L}^{-1}\right)$, yeast extract $\left(1.0 \mathrm{~g} \mathrm{~L}^{-1}\right)$ and agar $\left(15 \mathrm{~g} \mathrm{~L}^{-1}\right)$ in distilled water $(100 \mathrm{~mL}){ }^{30}$ The diets (0.4-0.5 g per dish) with the addition of limonoids (experiment) or without (control) were supplemented daily in small plastic caps. The control was prepared with the diet and the solvent. The compounds were poured into the hot diet immediately after it was autoclaved. The final concentration of the limonoids added to the diet was $100 \mu \mathrm{g}$ $\mathrm{mL}^{-1}$. To ensure that undetectable remaining amounts of the solvent did not affect the ants, a comparison was made with another set of dishes in which water was used instead of solvent. As expected, the same survival rates were obtained with both systems (data not shown). During the assays the material was maintained in an incubator at a temperature of $25( \pm 1){ }^{\circ} \mathrm{C}$ and relative humidity ranging between $70-80 \%$. The maximum length of observation was 25 days and the number of dead ants was recorded daily.

The survival average $50 \%\left(\mathrm{~S}_{50}\right)$ was calculated and survival curves were compared by the computer-assisted software Graph-Pad ${ }^{\mathrm{TM}}$ using the log-rank test. 


\section{Acknowledgments}

The authors are grateful to Dr. Maria Inês Salgueiro Lima for collecting and identifying the $C$. fissilis specimen and to the Conselho Nacional de Desenvolvimento Científico e Tecnológico (CNPq), Fundação de Amparo à Pesquisa do Estado de São Paulo (FAPESP), Coordenação de Aperfeiçoamento de Pessoal de Ensino Superior (CAPES) and Financiadora de Estudos e Projetos (FINEP) for the financial support.

\section{Supplementary Information}

Supplementary data are available free of charge as PDF file at http://jbcs.sbq.org.br

\section{References}

1. Da Silva, M. F. das G. F.; Gottlieb, O. R.; Dreyer, D. L.; Biochem. Syst. Ecol. 1984, 12, 299.

2. Champagne, D. E.; Koul, O.; Isman, M. B.; Scudder, G. G. E.; Towers, G. H. N.; Phytochemistry 1992, 31, 337.

3. Champagne, D. E.; Isman, M. B.; Towers, G. H. N. In Insecticides of Plant Origin; Arnason, J.T.; Philogéne, B. J. R.; Morand, P., eds.; The American Chemical Society: Washington, 1989, pp. 95109.

4. Hölldobler, B.; Wilson, E.O.; The Ants, Harvard University Press: Massachusetts, 1990.

5. Weber, N. A.; Gardening Ants, the Attines, The American Philosophical Society: Philadelphia, 1972.

6. Della-Lucia, T. M. C.; Fowler, H.G. In As Formigas Cortadeiras; Della-Lucia, T. M. C., ed.; Folha de Viçosa: Viçosa, 1993, pp. 1-3.

7. Williams, D. F. In Applied Myrmecology: A World Perspective; Vander-Meer, R. K.; Jaffe, K.; Cedeno, A., eds., Westview Press: San Francisco, 1990, pp. 493-495.

8. Acácio-Bigi, M. F. M.; Hebling, M. J. A.; Bueno, O .C.; Pagnocca, F. C.; Silva, O. A.; Fernandes, J. B.; Vieira, P. C.; Rev. Bras. Entomol. 1998, 41, 239; Monteiro, M. R.; Torkomian, V. L. V.; Pagnocca, F. C.; Vieira, P. C.; Fernandes, J. B.; Da Silva, M. F. das G. F.; Bueno, O. C.; Hebling, M. J. A.; An. Acad. Bras. Cienc. 1998, 70, 733; Pagnocca, F. C.; Ribeiro, S. B.; Torkomian, V. L. V.; Hebling, M. J. A.; Bueno, O. C.; Silva, O. A.; Fernandes, J. B.; Vieira, P. C.; Ferreira, A. G.; J. Chem. Ecol. 1996, 22, 1325; Ribeiro, S. B.; Pagnocca, F. C.; Victor, S. R.; Bueno, O. C.; Hebling, M. J. A.; Bacci-Júnior, M.; Silva, O. A.; Fernandes, J. B.; Vieira, P. C.; An. Soc. Entomol. Brasil 1998, 27, 421; Rodrigues-Gamboa, T. P.; Victor, S. R.; Fernandes, J. B.; Rodrigues-Filho, E.; Da Silva, M. F. G. F.; Vieira, P. C.; Pagnocca, F. C.; Bueno, O. C.; Hebling, M. J. A.; Castro, O. C.; Phytochemistry 2000, 55, 837; Leite, A. C.; Bueno, F. C.; Oliveira, C. G.; Fernandes, J. B.; Vieira, P. C.; Da Silva, M. F.das G. F.; Bueno, O. C.; Pagnocca, F. C.; Hebling, M. J. A.; Bacci-Júnior, M.; J. Braz. Chem. Soc. 2005, 16, 1391.
9. Bickii, J.; Njifutie, N.; Foyere, J. A.; Basco, L. K.; Ringwald, P.; J. Ethnopharmacol. 2000, 69, 27.

10. Gilbert, B.; Teixeira, D. F.; Carvalho, E. S.; Paula, A. E. S.; Pereira, J. F. G.; Ferreira, J. L. P.; Almeida, M. B. S.; Machado, R. S.; Cascon, V.; An. Acad. Bras. Cienc. 1999, 71, 265.

11. MacKinnon, S.; Durst, T.; Arnason, J. T.; J. Nat. Prod. 1997, 60, 336.

12. Moura, M. D.; Souza-Silva, J.; De Oliveira, R. A. G.; Diniz, M. F. F. M.; Barbosa-Filho, J. M.; Acta Farm. Bonaerense 2002, 27,61 .

13. Lavie, D.; Levy, E. C.; Zelnik, R.; Bioorg. Chem. 1972, 2, 59.

14. Marcelle, B. G.; Moto, B. S.; Phytochemistry 1975, 14, 2717.

15. Ollis, W. D.; Ward, A. D.; De Oliveira, H. M.; Zelnik, R.; Tetrahedron 1970, 26, 1637.

16. Ollis, W. D.; Ward, A. D.; Zelnik, R.; Tetrahedron Lett. 1964, 37, 2607.

17. Qi, S. H.; Wu, D. G.; Ma, Y. B.; Luo, X. D.; Acta Bot. Sin. 2003, 45, 1129; Qi, S. H.; Wu, D. G.; Zhang, S.; Luo, X. D.; Pharmazie 2004, 59, 488.

18. Trindade, M. B.; Msc. Dissertation, Universidade Federal de São Carlos, Brazil, 2000.

19. Zelnik, R.; Tetrahedron Lett. 1966, 52, 6441; Zelnik, R.; Phytochemistry 1970, 10, 1955.

20. Ambrozin, A. R. P.; Msc. Dissertation, Universidade Federal de São Carlos, Brazil, 2000.

21. Bueno, F. C.; Godoy, M.P.; Leite, A. C.; Bueno, O. C.; Pagnocca, F. C.; Fernandes, J.B.; Hebling, M. J. A.; Bacci Jr, M.; J. Appl. Ent., submitted.

22. Kraus, W.; Cramer, R.; Tetrahedron Lett. 1978, 27, 2395.

23. Sierra, M. G.; Khalid, S. A.; Duddeck, H.; Fitoterapia 1989, 60, 99; Khalid, S. A.; Duddeck, H.; Sierra, M. G.; J. Nat. Prod. 1989, 52, 922.

24. Céspedes, C. L.; Calderón, J. S.; King-Diaz, B. E.; LotinaHennsen, B.; J. Agric. Food Chem. 1998, 46, 2810.

25. Banergi, B.; Nigam, S.K.; Fitoterapia 1984, 55, 3.

26. Ekong, D. E. U.; Olagbemi, E. O.; Tetrahedron Lett. 1967, 36, 3525 .

27. Housley, J. R.; King, F. E.; King, T. J.; Taylor, P. R.; J. Chem. Soc., C 1962, 5095.

28. Kokpol, U.; Chavasiri, W.; Tip-Pyang, S.; Veerachato, G.; Zhao, F.; Simpson, J.; Weavers, R. T.; Phytochemistry 1996, $41,903$.

29. Govindachari, T. R.; Narasimhan, N. S.; Suresh, G.; Partho, P. D.; Gopalakrishman, G.; Kumari, G. N. K.; J. Chem. Ecol. 1995, 21,1585 .

30. Bueno, O. C.; Morini, M. S. C.; Pagnocca, F. C.; Hebling, M. J. A.; Silva, O. A.; An. Soc. Entomol. Bras. 1997, 26, 107.

Received: November 16, 2004 Published on the web: April 7, 2006

FAPESP helped in meeting the publication costs of this article. 


\section{Limonoids from Andiroba Oil and Cedrela fissilis and their Insecticidal Activity}

\section{Alessandra R. P. Ambrozin, ${ }^{a}$ Ana C. Leite, ${ }^{a}$ Fabiana C. Bueno, ${ }^{b}$ Paulo C. Vieira, ${ }^{*, a}$} João B. Fernandes, ${ }^{a}$ Odair C. Bueno, ${ }^{b}$ M. Fátima das G. Fernandes da Silva, ${ }^{a}$ Fernando C. Pagnocca, ${ }^{b}$ M. José A. Hebling ${ }^{b}$ and Maurício Bacci Jr. ${ }^{b}$

${ }^{a}$ Departamento de Química, Universidade Federal de São Carlos, CP 676, 13565-905 São Carlos - SP, Brazil

${ }^{b}$ Centro de Estudos de Insetos Sociais, Universidade Estadual Paulista, CP 199, 13506-900 Rio Claro - SP, Brazil

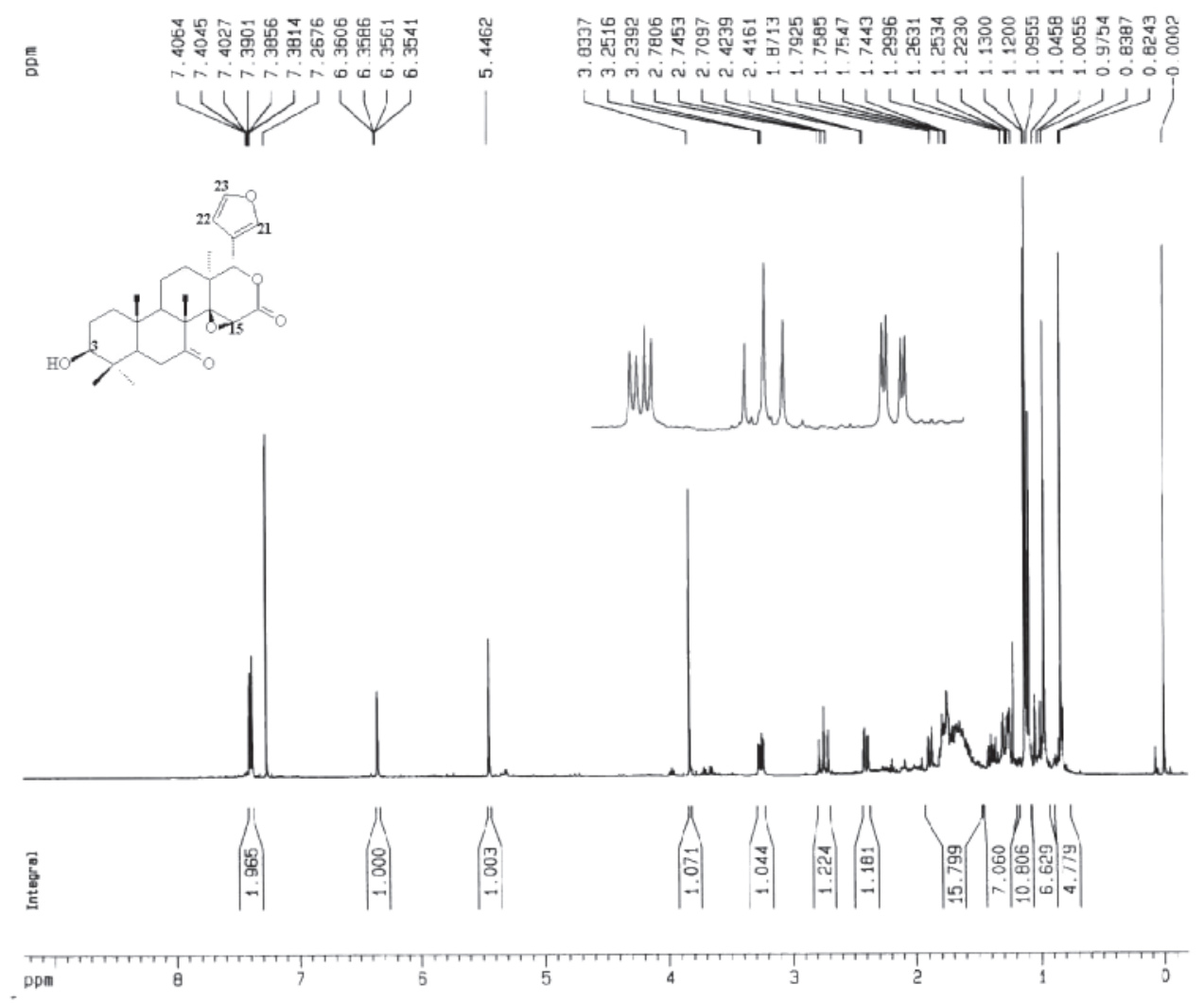

Figure S1. NMR ${ }^{1} \mathrm{H}$ spectra of $5\left(400 \mathrm{MHz}, \mathrm{CDCl}_{3}\right)$.

* e-mail: paulo@dq.ufscar.br 


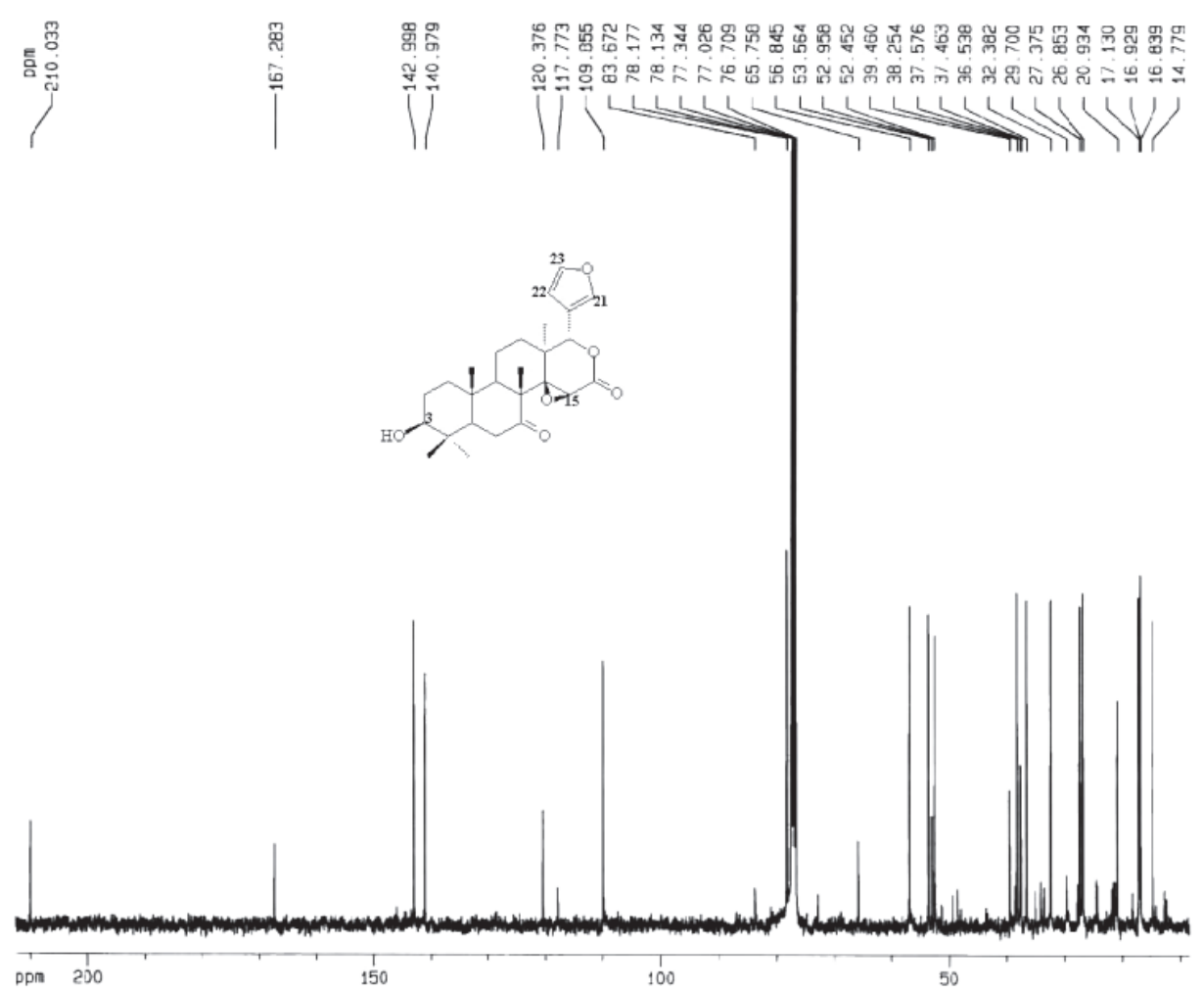

Figure S2. $\mathrm{NMR}{ }^{13} \mathrm{C}$ spectra of $\mathbf{5}\left(100 \mathrm{MHz}, \mathrm{CDCl}_{3}\right)$.

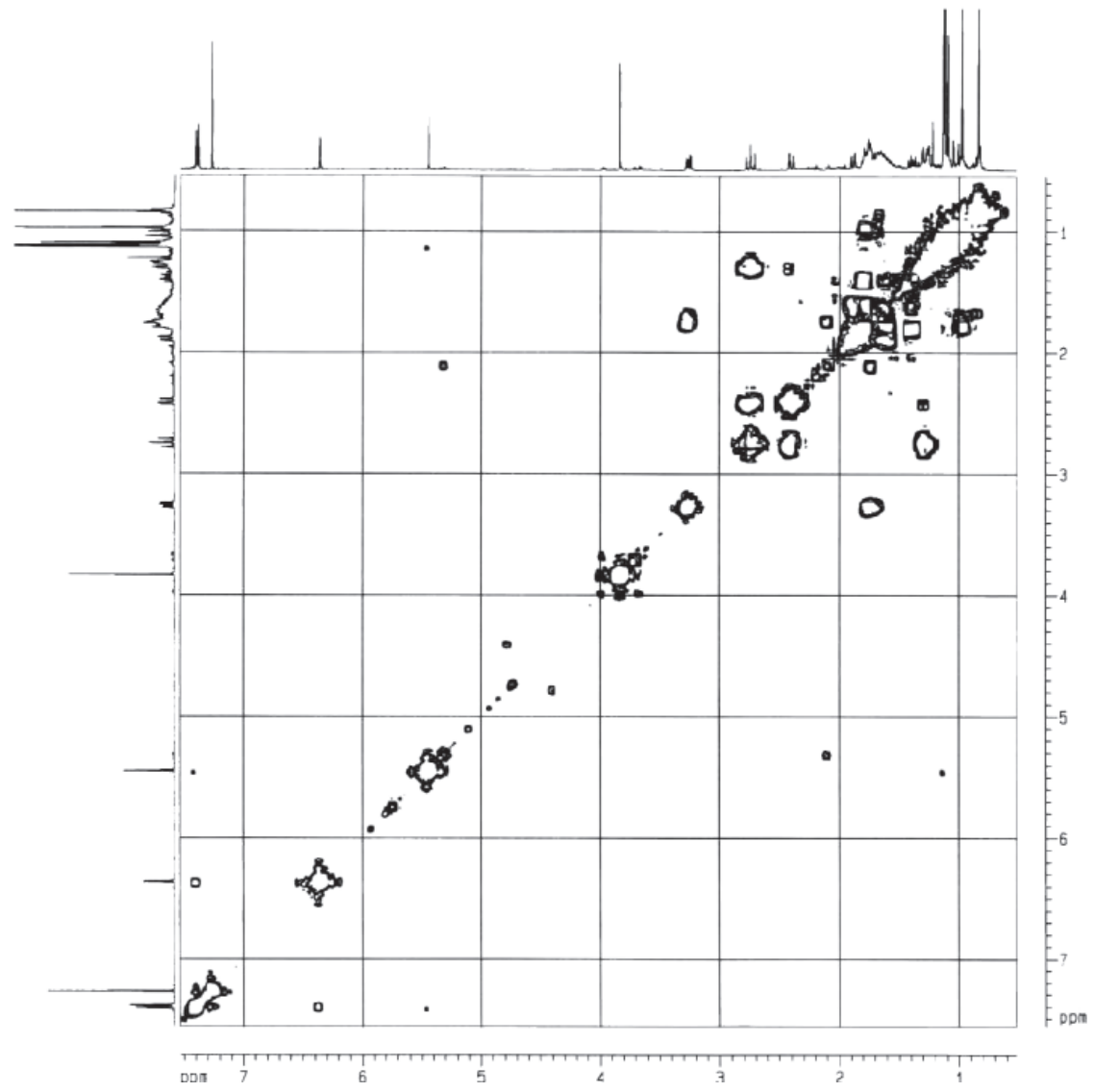

Figure S3. COSY ${ }^{1} \mathrm{H}^{-1} \mathrm{H} 45^{\circ}$ spectra of $5\left(400 \mathrm{MHz}, \mathrm{CDCl}_{3}\right)$ A. 


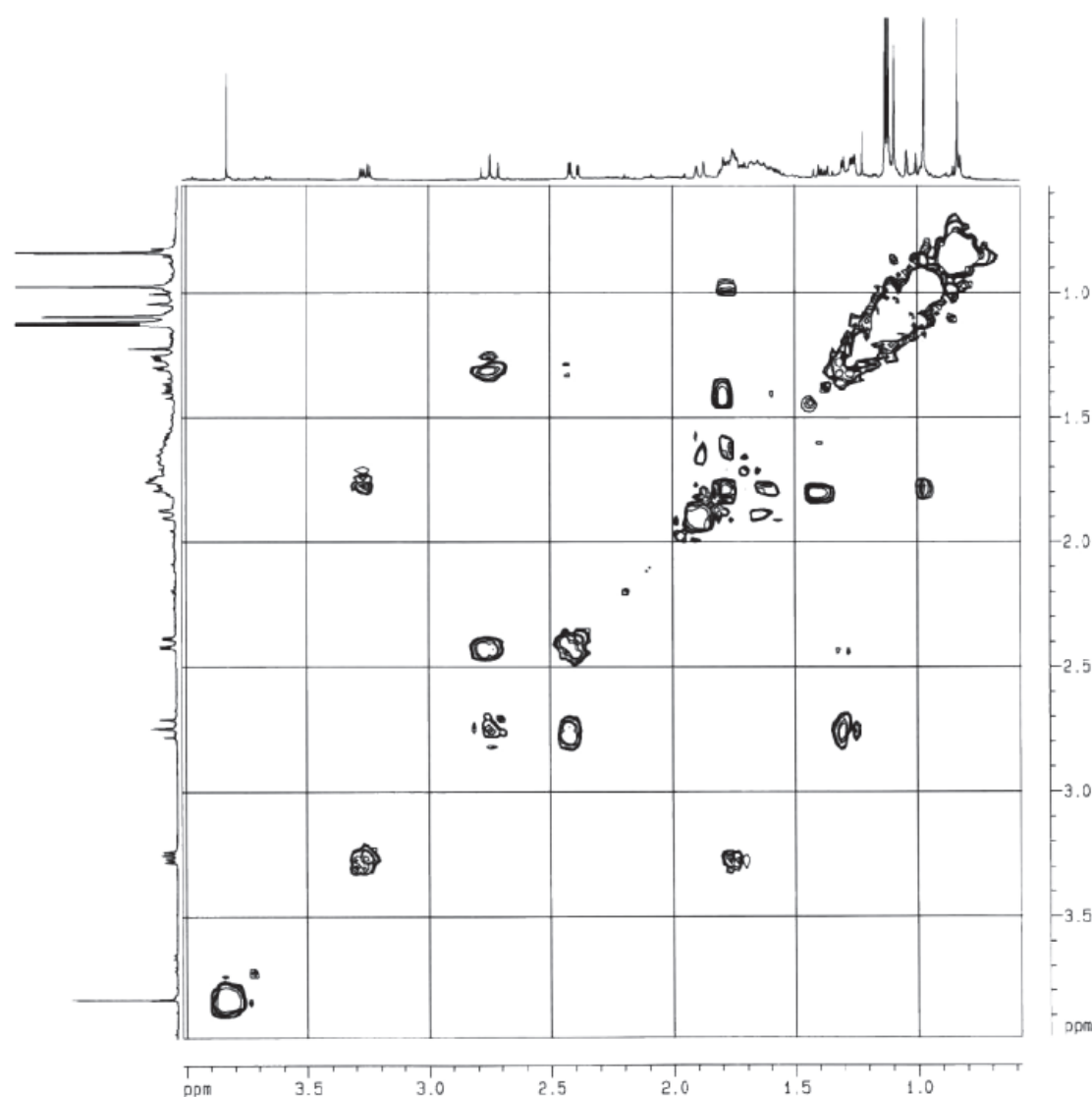

Figure S4. $\operatorname{COSY}{ }^{1} \mathrm{H}^{-1} \mathrm{H} 45^{\circ}$ spectra of $\mathbf{5}\left(400 \mathrm{MHz}, \mathrm{CDCl}_{3}\right)$ B.

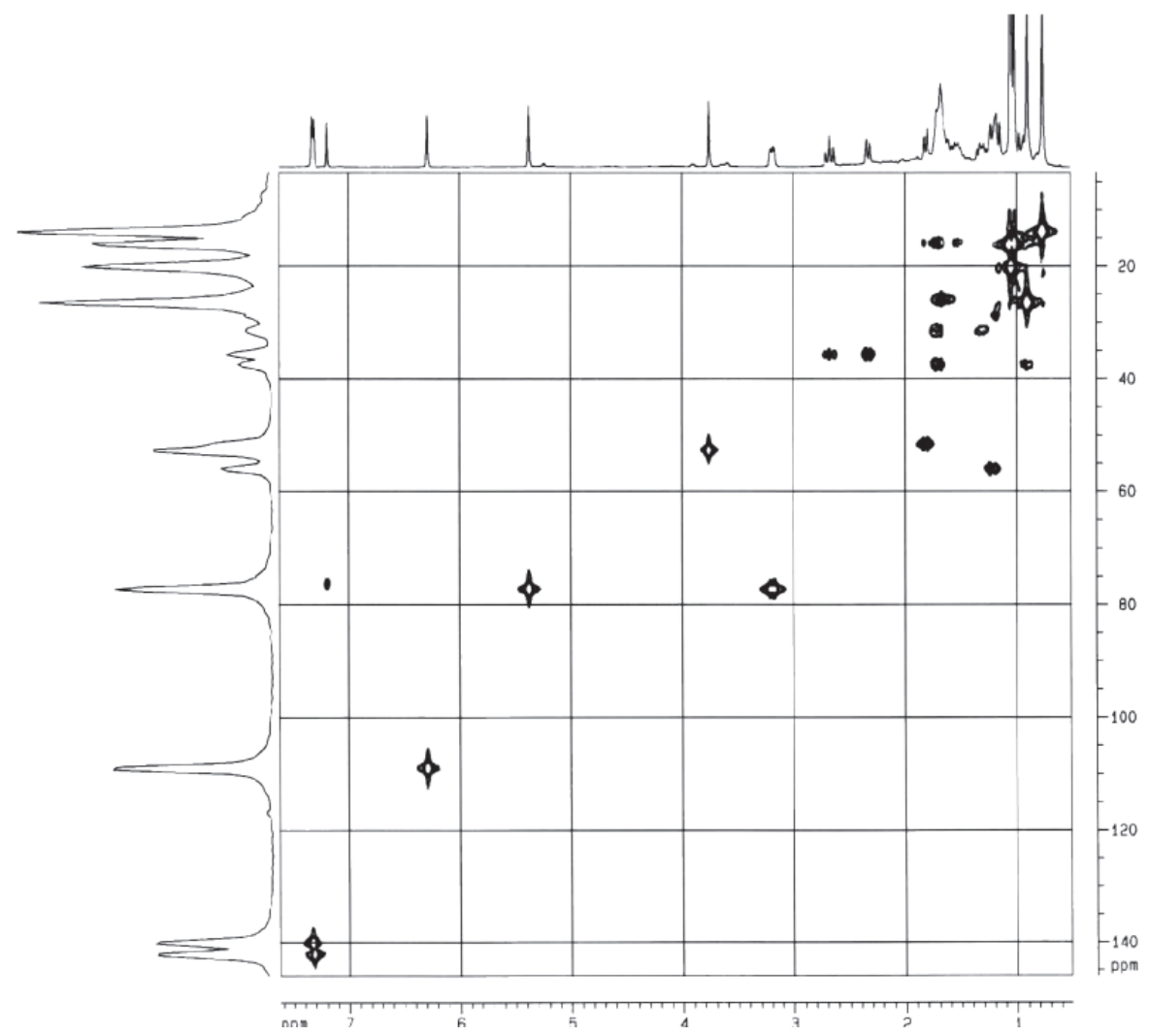

Figure S5. Correlation map HSQC of $5\left(400 \mathrm{MHz}, \mathrm{CDCl}_{3}\right)$. 


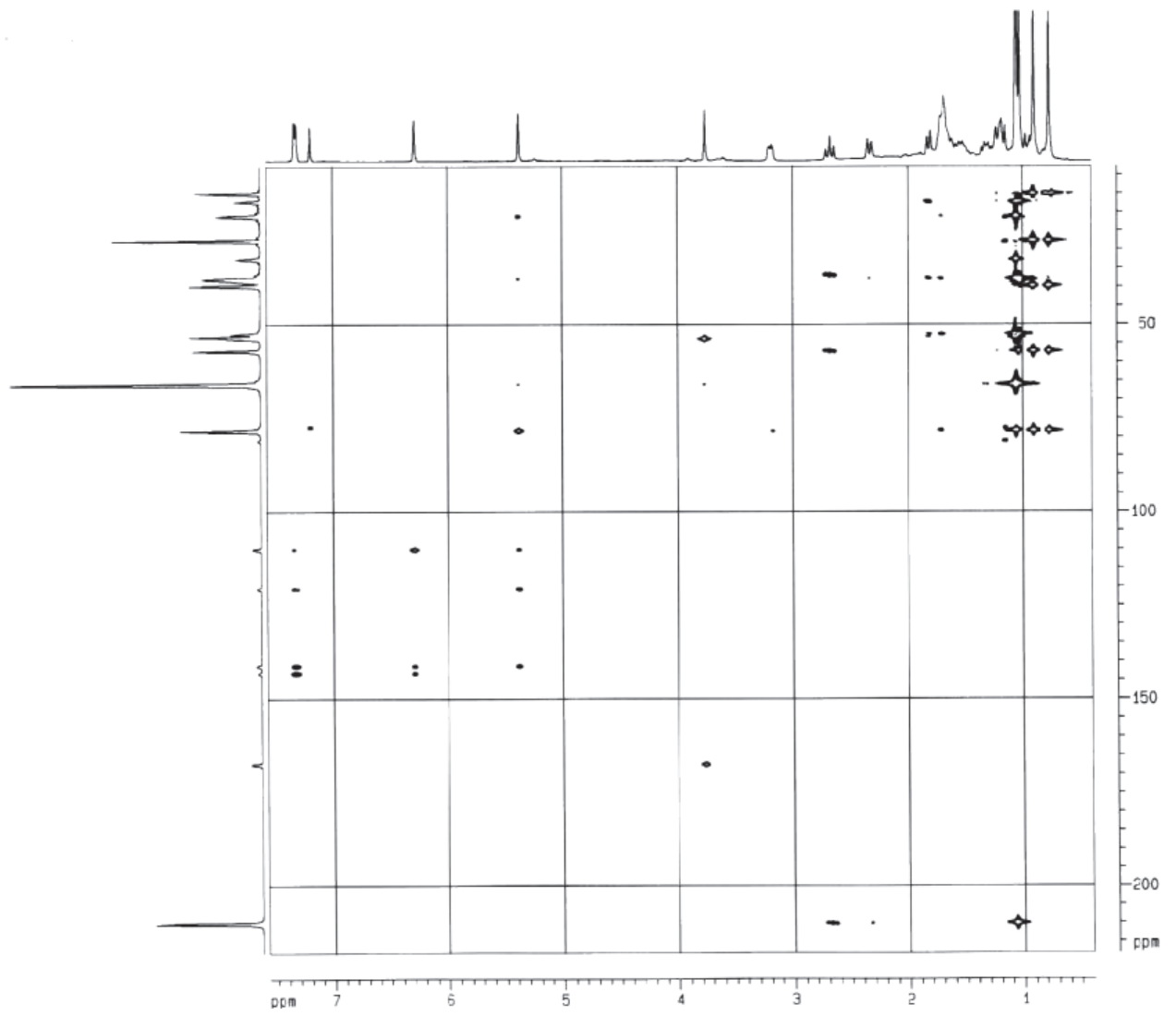

Figure S6. Correlation map HMBC of $5\left(400 \mathrm{MHz}, \mathrm{CDCl}_{3}\right)$ A.

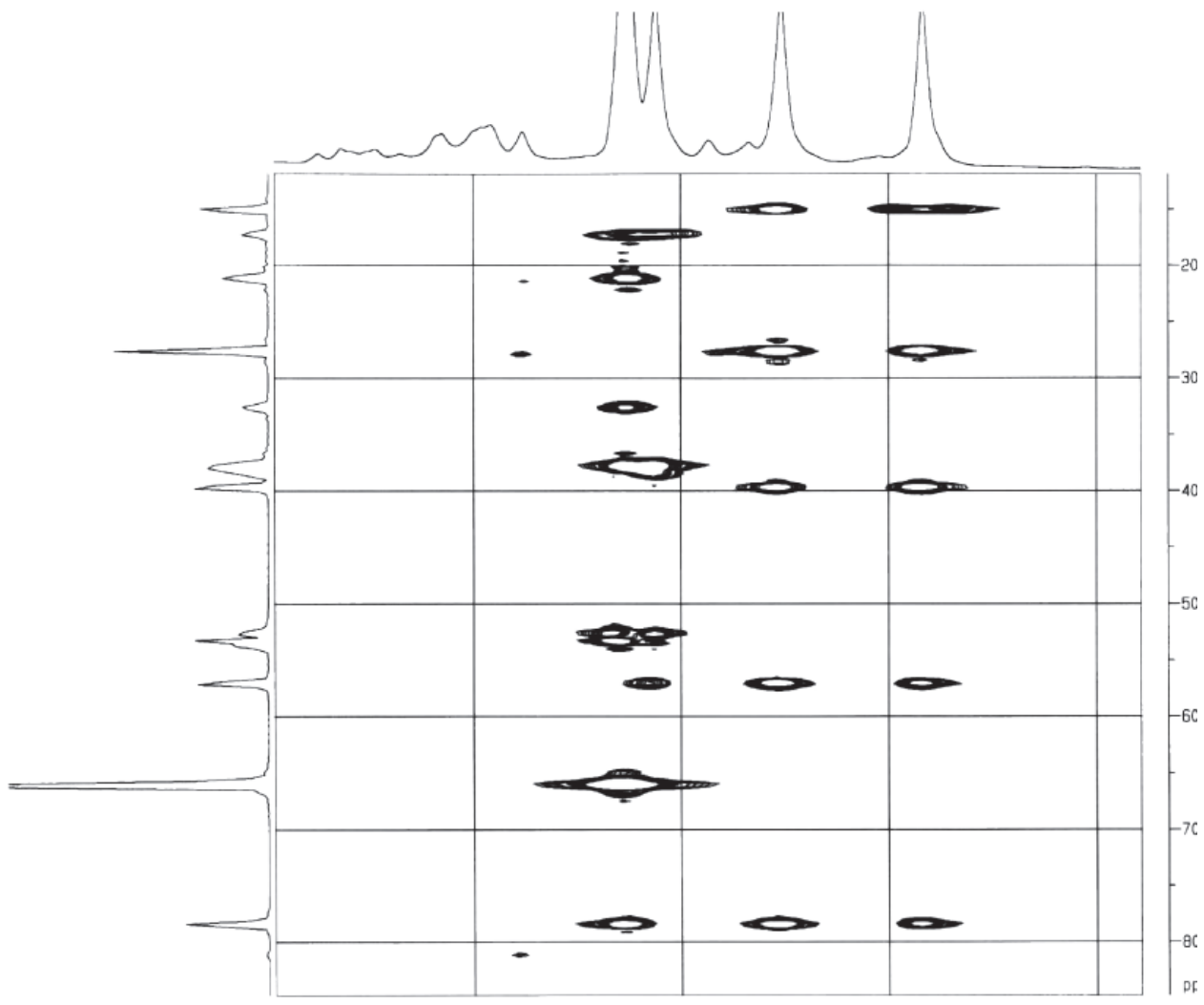

Figure S7. Correlation map HMBC of 5 (400 MHz, $\left.\mathrm{CDCl}_{3}\right)$ B. 


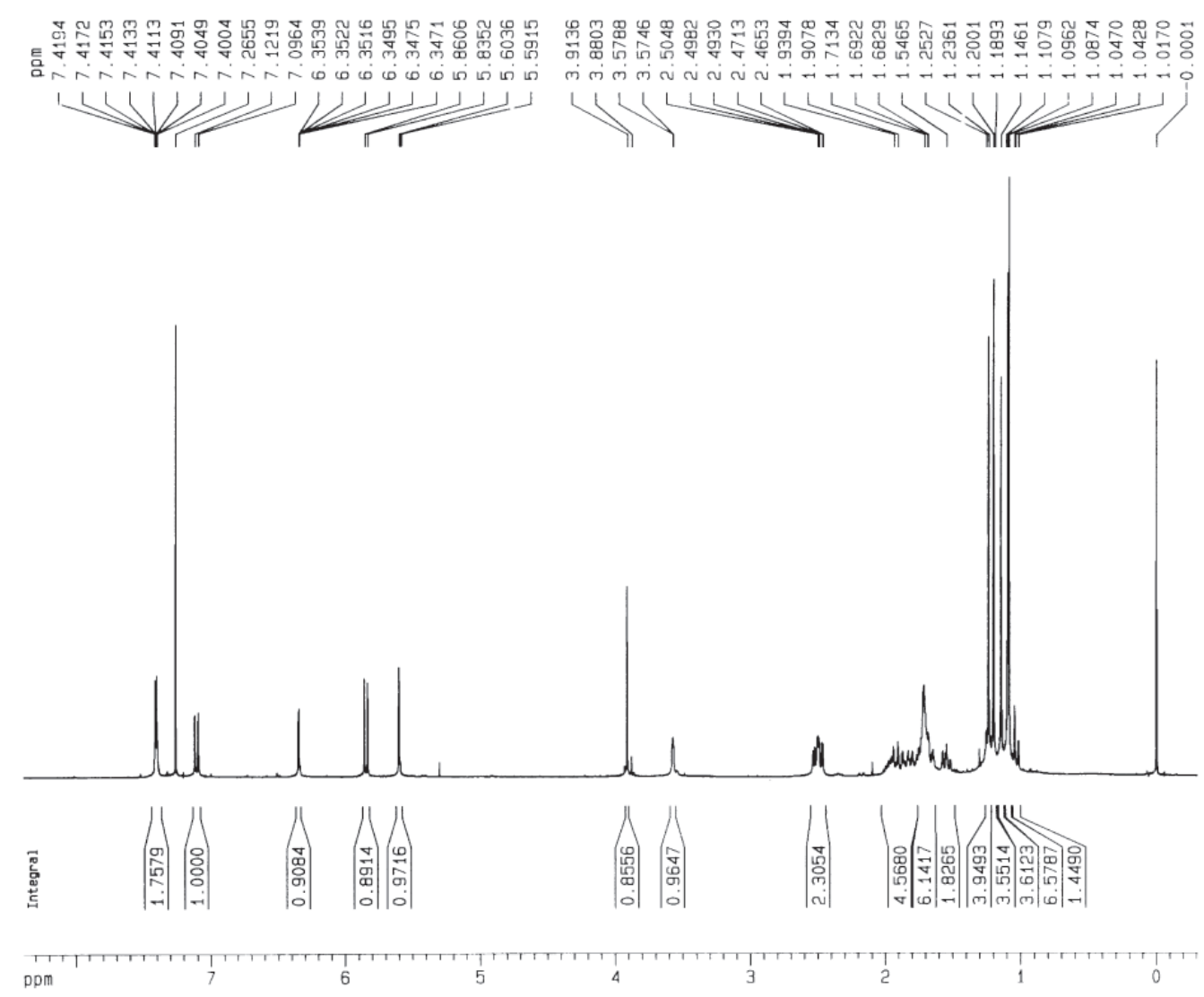

Figure S8. NMR ${ }^{1} \mathrm{H}$ spectra of $6\left(400 \mathrm{MHz}, \mathrm{CDCl}_{3}\right)$.
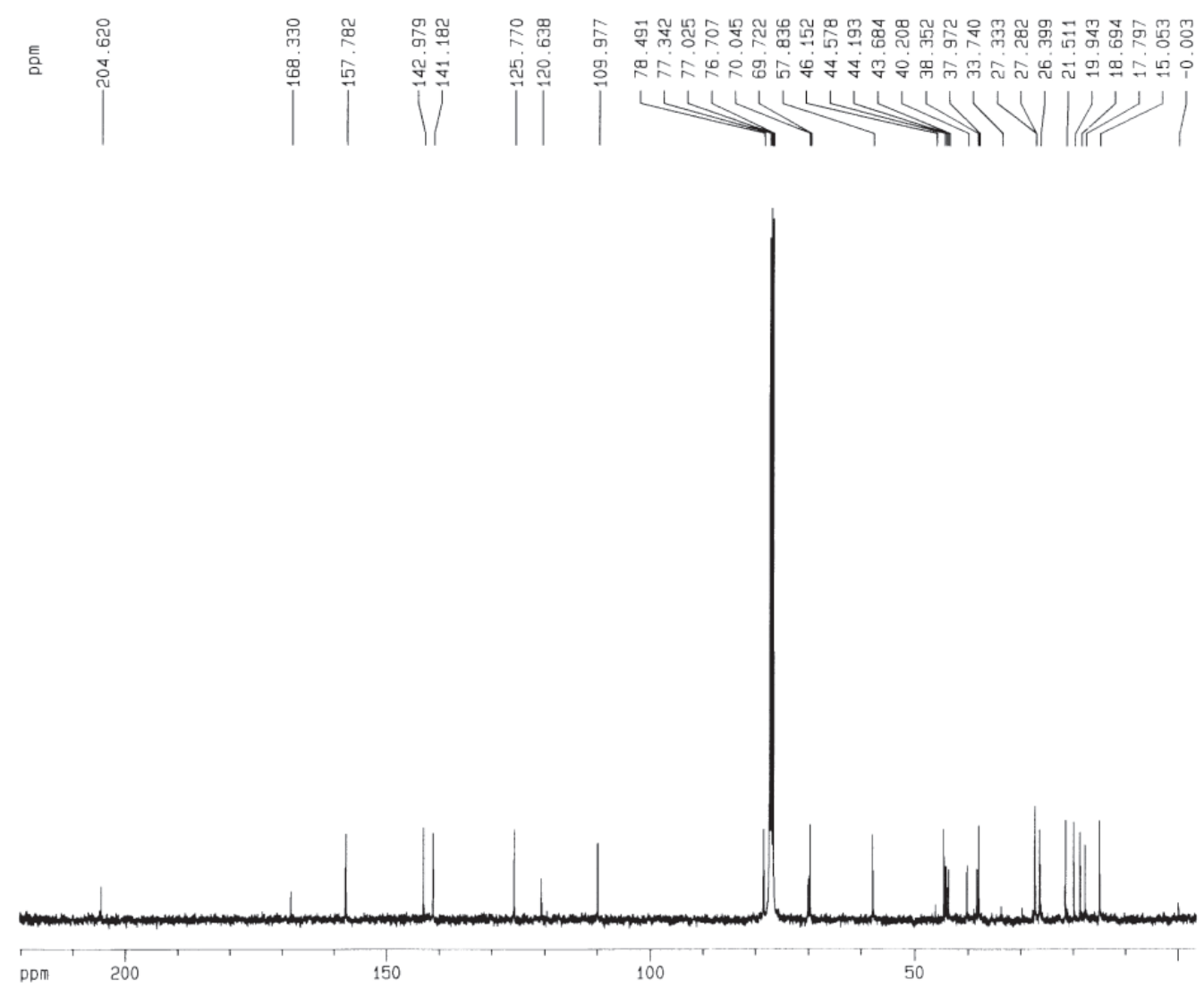

Figure S9. NMR ${ }^{13} \mathrm{C}$ spectra of $6\left(100 \mathrm{MHz}, \mathrm{CDCl}_{3}\right)$. 


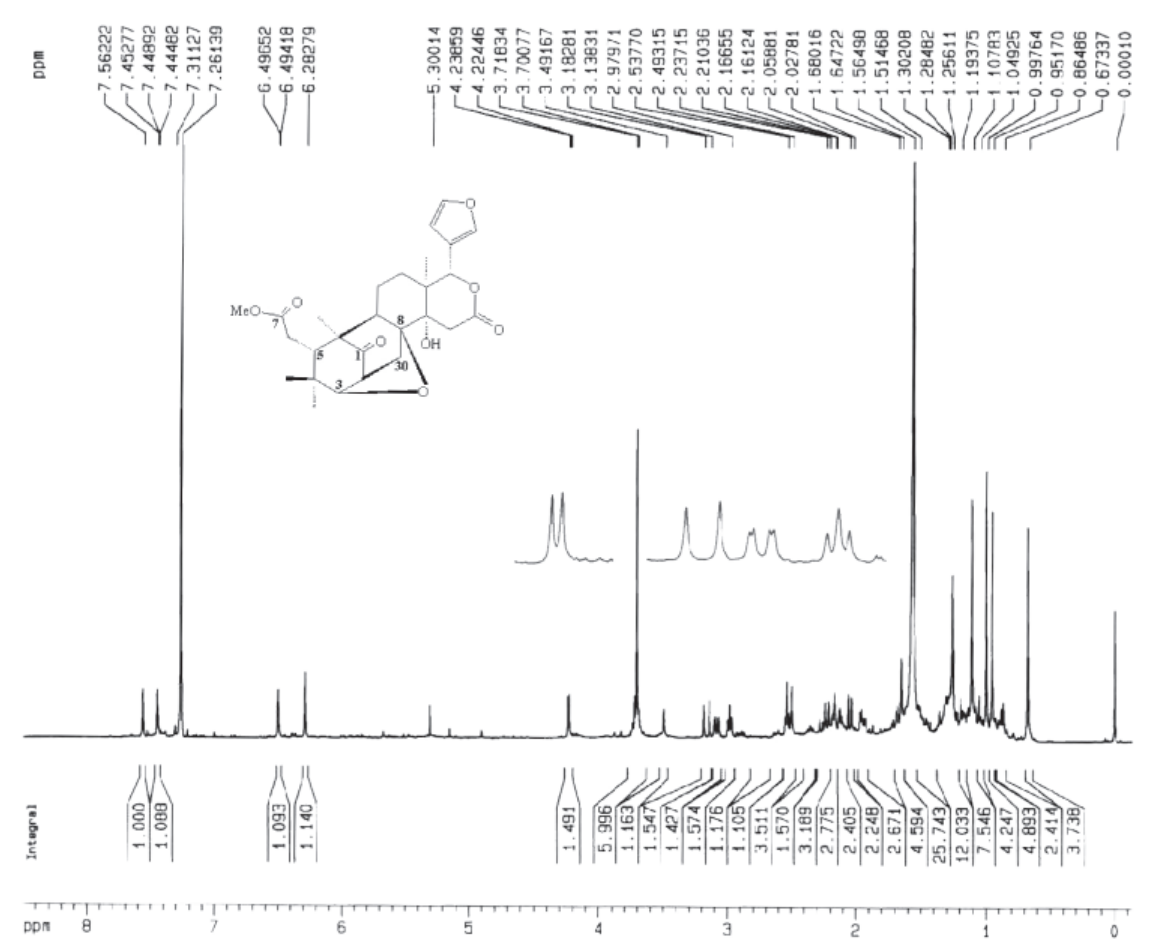

Figure S10. NMR ${ }^{1} \mathrm{H}$ spectra of $9\left(400 \mathrm{MHz}, \mathrm{CDCl}_{3}\right)$.

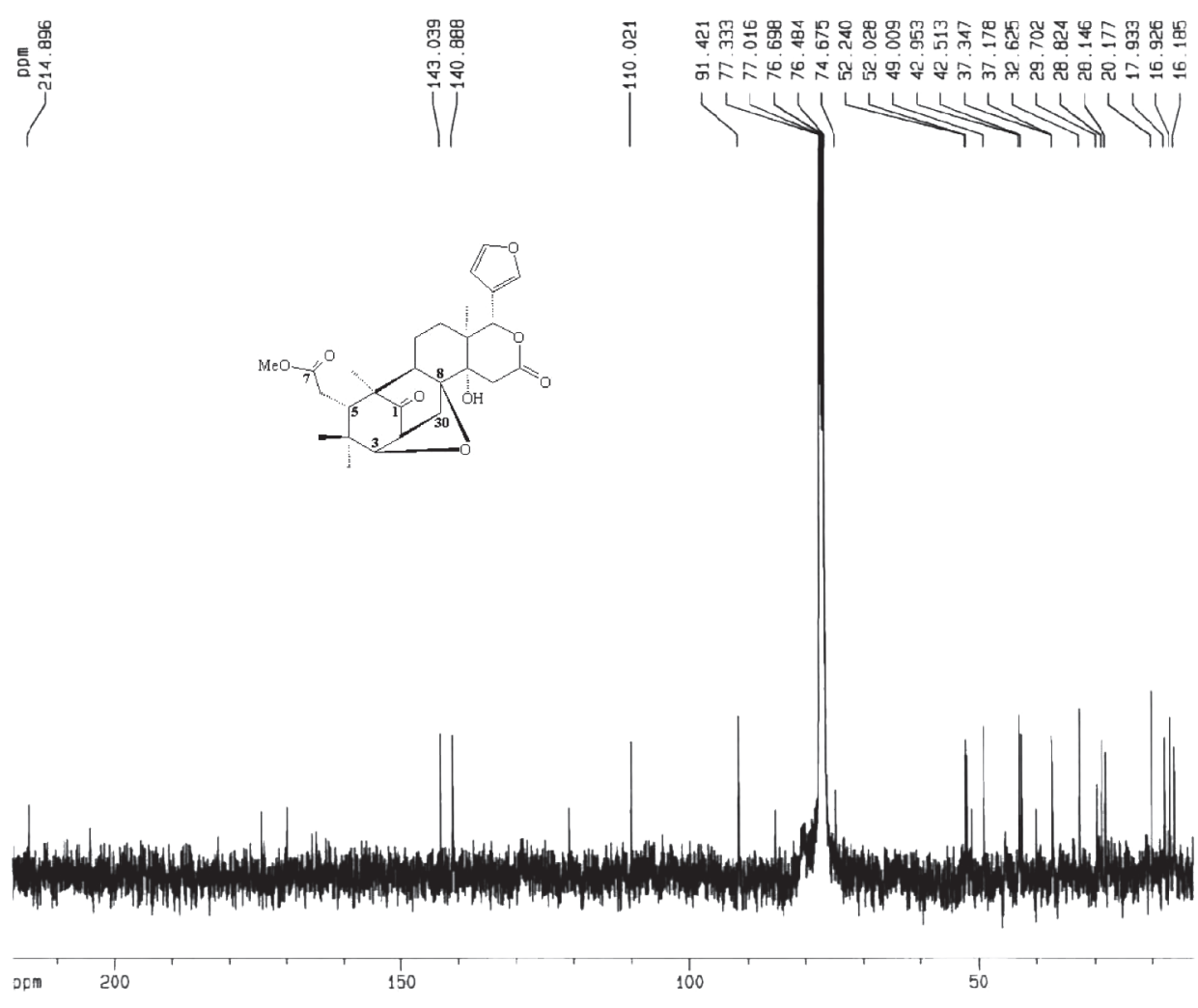

Figure S11. $\mathrm{NMR}{ }^{13} \mathrm{C}$ spectra of $9\left(100 \mathrm{MHz}, \mathrm{CDCl}_{3}\right)$. 


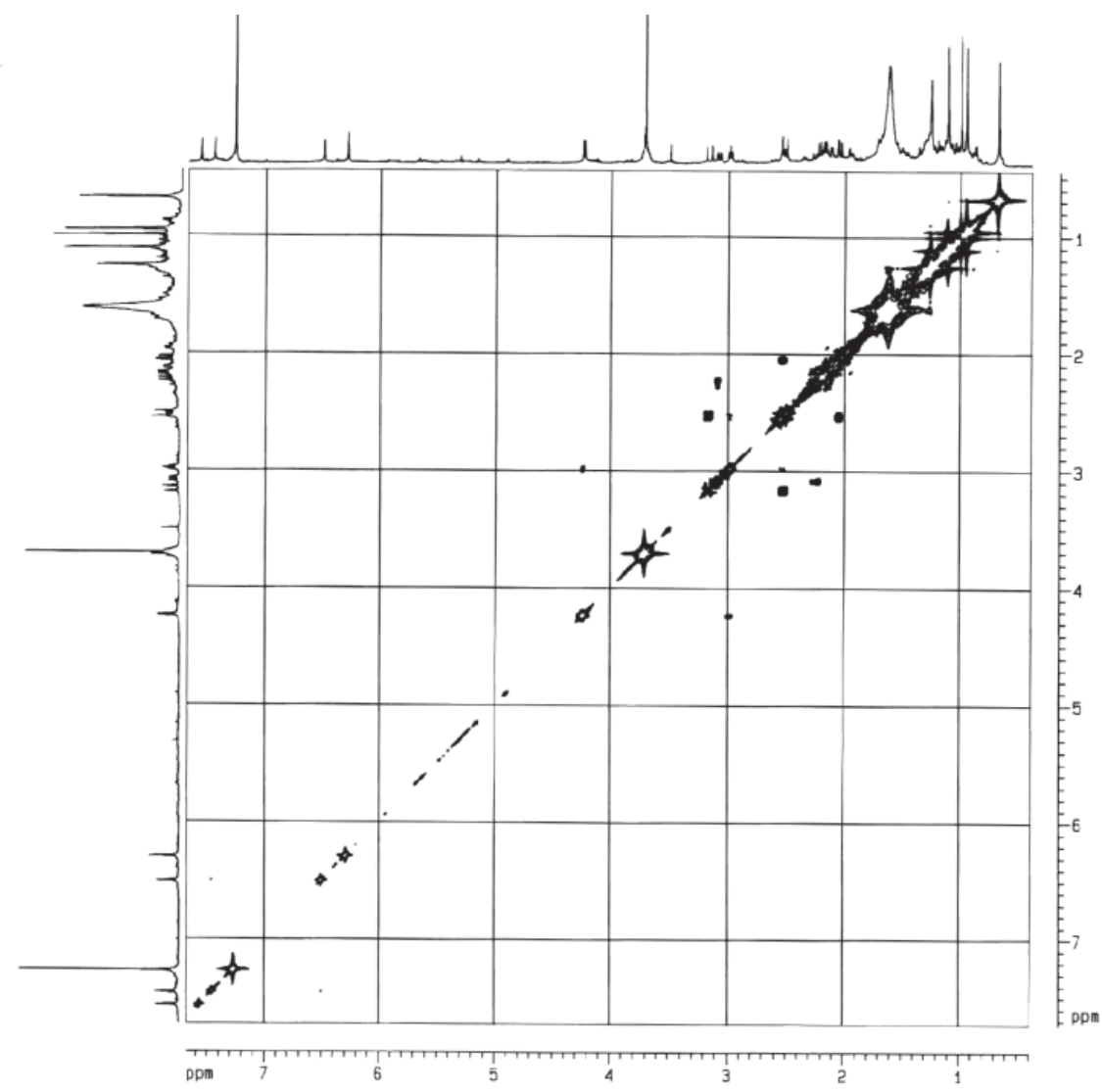

Figure S12. COSY ${ }^{1} \mathrm{H}-{ }^{1} \mathrm{H} 45^{\circ}$ spectra of $9\left(400 \mathrm{MHz}, \mathrm{CDCl}_{3}\right) \mathrm{A}$.

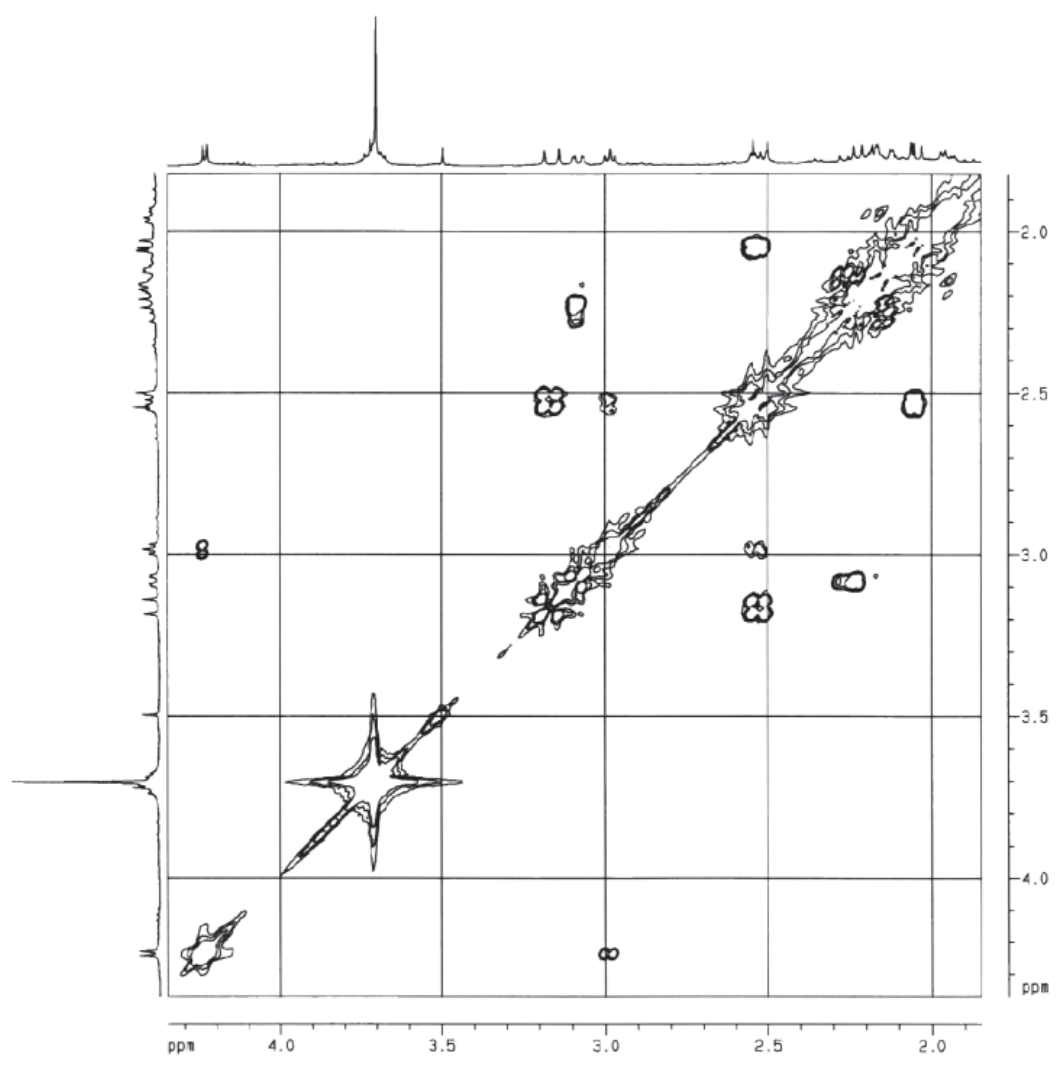

Figure S13. COSY ${ }^{1} \mathrm{H}^{-1} \mathrm{H} 45^{\circ}$ spectra of $9\left(400 \mathrm{MHz}, \mathrm{CDCl}_{3}\right) \mathrm{B}$. 


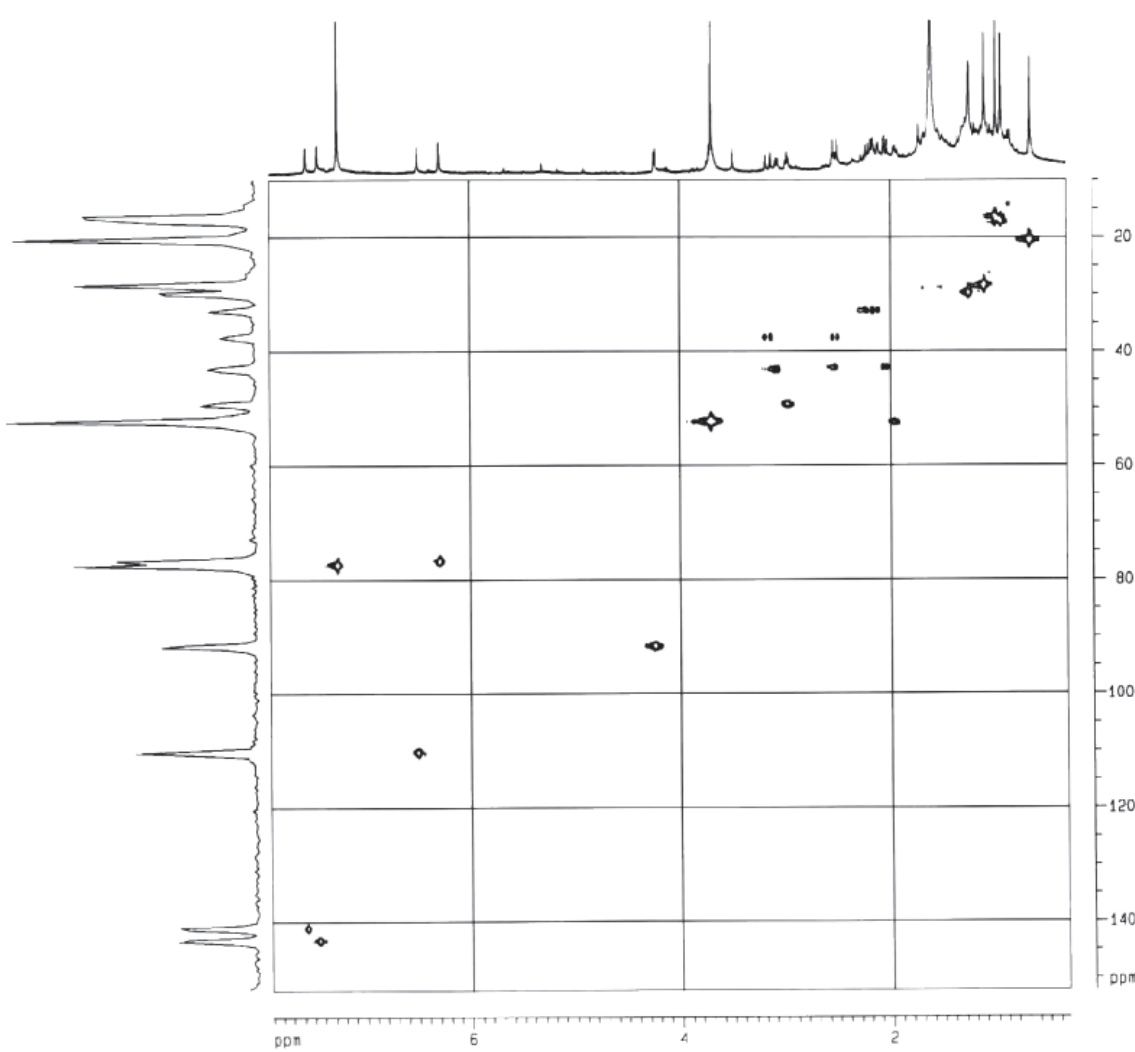

Figure S14. Correlation map HSQC of $9\left(400 \mathrm{MHz}, \mathrm{CDCl}_{3}\right)$ A.

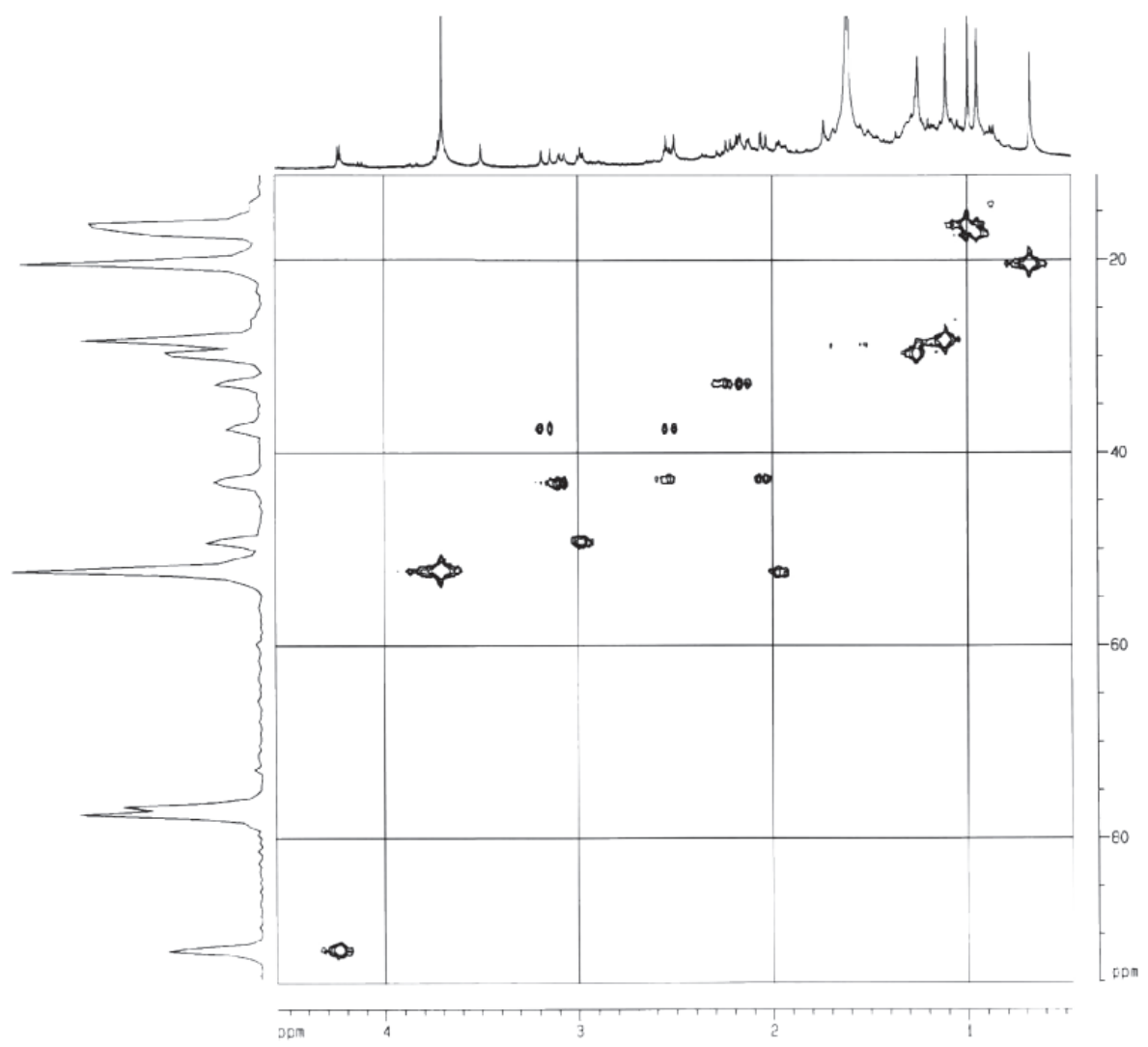

Figure S15. Correlation map HSQC of $\mathbf{9}\left(400 \mathrm{MHz}, \mathrm{CDCl}_{3}\right)$ B. 


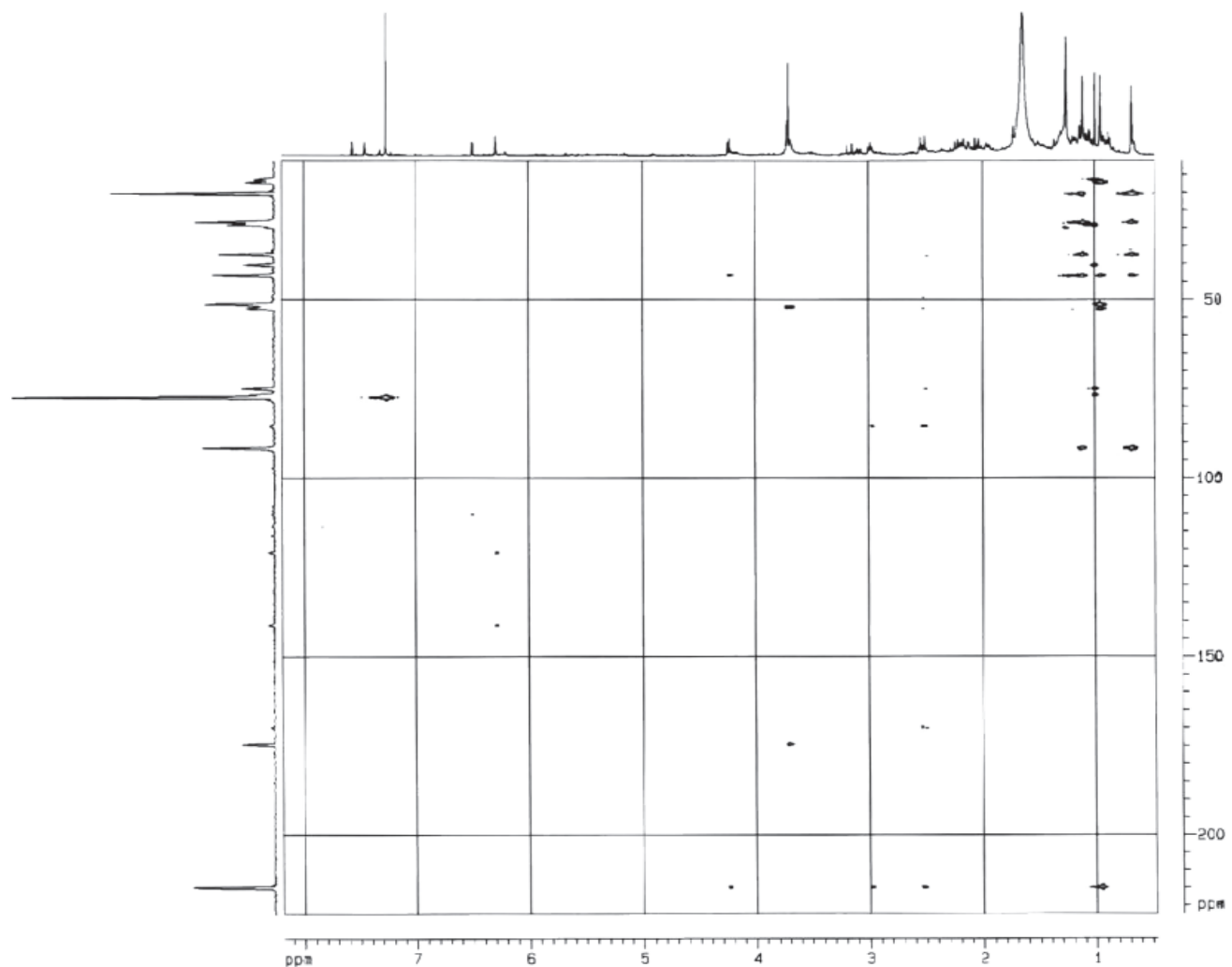

Figure S16. Correlation map $\mathrm{HMBC}$ of $9\left(400 \mathrm{MHz}, \mathrm{CDCl}_{3}\right)$ A.

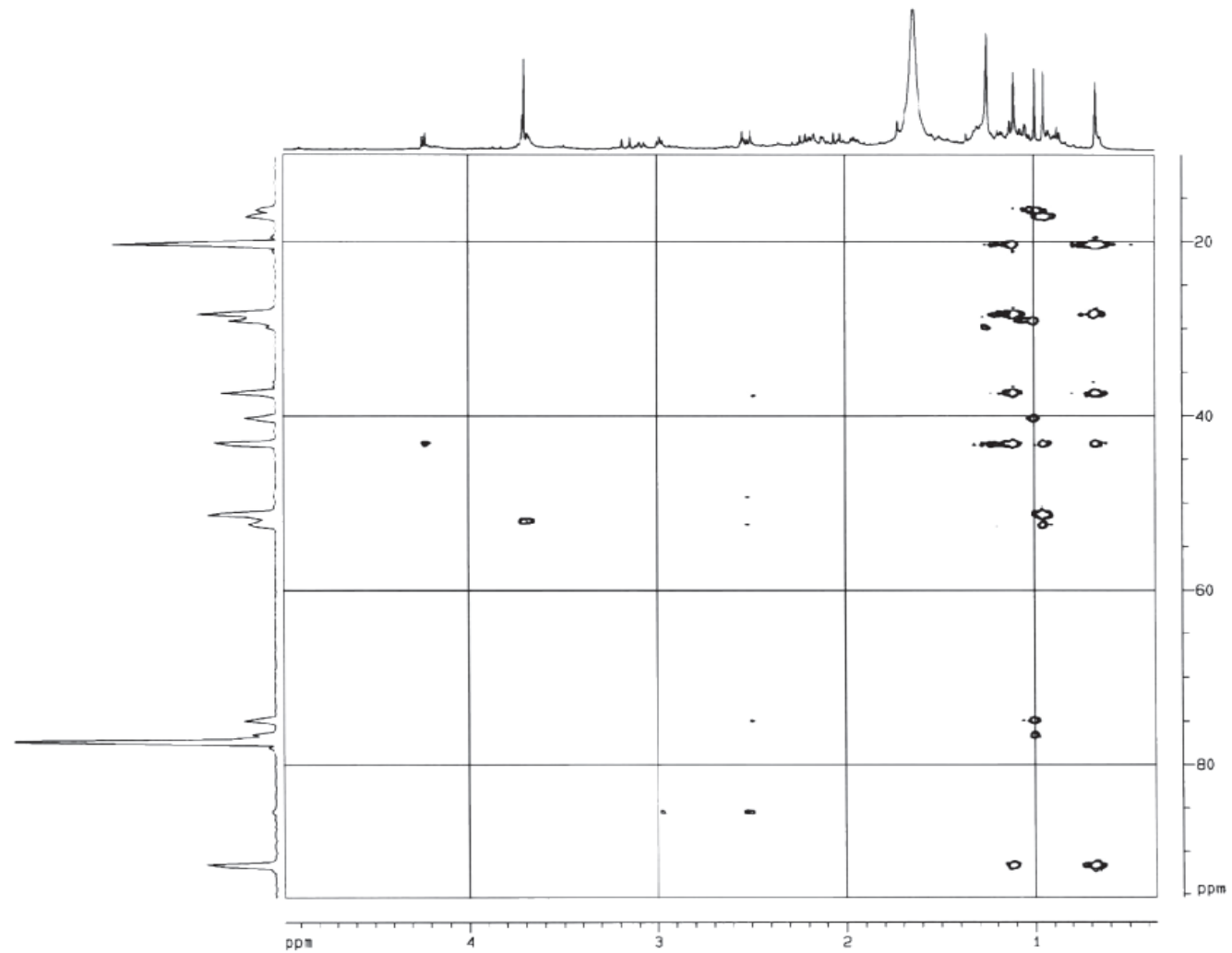

Figure S17. Correlation map $\mathrm{HMBC}$ of $9\left(400 \mathrm{MHz}, \mathrm{CDCl}_{3}\right)$ B. 